\title{
REPÚBLICA E CONSTITUIÇÃO DE 1988: OU CONSTITUIÇÃO SEM REPÚBLICA?
}

\author{
REPUBLIC AND THE $1988^{\circ}$ 'S CONSTITUTION: OR CONSTITUTION WITHOUT \\ REPUBLIC?
}

\section{REPÚBLICA Y CONSTITUCIÓN DE 1988: ¿O CONSTITUCIÓN SIN REPÚBLICA?}

\author{
Alexandre Gustavo Melo Franco Moraes Bahia \\ https://orcid.org/0000-0001-5461-7848 / http://lattes.cnpq.br/2877462978948032 / alexprocesso@gmail.com \\ Universidade Federal de Ouro Preto - UFOP \\ Ouro Preto, MG, Brasil. \\ Diogo BaCHA E SILVA \\ https://orcid.org/0000-0001-9748-0714 / http://lattes.cnpq.br/0134685542487401 / diogobacha@ig.com.br \\ Faculdade de São Lourenço. \\ São Lourenço, MG, Brasil
}

\begin{abstract}
RESUMO
O texto percorre a história constitucional brasileira para demonstrar qual o ideário republicano que permeia a construção da história do nosso constitucionalismo. Indaga-se a efetiva existência de práticas republicanas na Constituição de 1988, a partir da história constitucional, bem como alguns problemas que inviabilizam a caracterização da República na Constituição de 1988. Dentre tais problemas, situa-se a reforma política, a cultura de golpe de estado e o presidencialismo de coalizão. Através de um método histórico-conceitual e jurídico-reflexivo, a conclusão é que ainda temos um projeto republicano inacabado.
\end{abstract}

Palavras-chave: República; Constituição de 1988; história constitucional.

\begin{abstract}
The text goes through the Brazilian constitutional history to demonstrate which republican ideology that did not permeates the construction of the history of our constitutionalism. We question is the effective existence of republican practices in the 1988 Constitution, based on constitutional history, as well as some problems that make the characterization of the Republic unfeasible in the 1988 Constitution. Among these problems, there is political reform, the coup culture of state and the coalition presidentialism. Through a historical-conceptual and law-reflexive method, the conclusion is that we still have an unfinished republican Project
\end{abstract}

Keywords: Republic; $1988^{\prime}$ 's Constitution; constitutional history.

\section{RESUMEN}

El texto revisa la historia constitucional brasileña para demostrar qué ideología republicana que impregna o no la construcción de la historia de nuestro constitucionalismo. Cuestionamos la existencia efectiva de prácticas republicanas en la Constitución de 1988, basadas en la historia constitucional, así como algunos problemas que hacen inviable la caracterización de la República en la Constitución de 1988. del presidencialismo estatal y de coalición. A través de un método histórico-conceptual y legal-reflexivo, la conclusión es que todavía tenemos un proyecto republicano inacabado.

Palabras clave: República; Constitución de 1988; historia constitucional. 


\section{SUMÁRIO}

INTRODUÇAO; 1 TEORIA DA HISTÓRIA: PROBLEMATIZANDO A CONSTRUÇÃO DOS CONCEITOS A PARTIR DA NECESSIDADE DE ANÁLISE DO TEMPO COMO CONSTRUÇÃO SÓCIO-CULTURAL EM KOSELLECK ; 2 REPÚBLICA E AUTORIDADE: A CONVIVÊNCIA CONFLITUOSA ENTRE A IDEIA REPUBLICANA E A CULTURA DE GOLPE; 3. OS PROBLEMAS DA TRANSIÇÃO: DO REGIME AUTORITÁRIO AO REGIME DEMOCRÁTICO; 4. REPÚBLICA APERFEIÇOADA OU REPÚBLICA INACABADA? O TEXTO CONSTITUCIONAL E AS TENTATIVAS DE IMPLEMENTAÇÃO DO PROJETO REPUBLICANO; CONCLUSÃO; REFERÊNCIAS.

“Agitem o povo. A República não está proclamada.” Benjamin Constant RJ, 15.11.1889

\section{INTRODUÇÃO}

A exigência da construção de uma comunidade republicana fez-se sentir com mais vigor ainda após a vigência de 6 (seis) projetos constitucionais em pouco mais de 166 (cento e sessenta e seis anos) de Estado Brasileiro independente.

Todos os projetos constitucionais a partir da proclamação da República, quais sejam 1891, 1934, 1937, 1946, 1967 e, agora, 1988, pretenderam fundar um projeto republicano e democrático. Ao menos formalmente, todos os textos constitucionais (1891, 1934, 1937, 1946, 1967, EC 1/69, 1988) mencionam, logo no primeiro artigo, a fundação de um Estado republicano. Consolidando o ato que deu origem à república, a saber, o golpe militar que depôs a família real. Quer isto significar que a prioridade dos projetos constitucionais sempre foi estabelecer uma república democrática.

Entretanto, a mera positivação da palavra república no texto constitucional é capaz de fundar um projeto republicano? Se não, o que nós consideramos como república? Houve efetiva implantação da república com a proclamação em 1889? Os demais projetos constitucionais conseguiram efetivar o ideal republicano? Tais projetos influenciam o ideário republicano de 1988? O que é República no projeto constitucional de 1988?

Extremamente importante definirmos qual conceito tivemos de República e se conseguimos efetivar um estado republicano. Por mais que se possa pensar que problematizar historicamente o conceito de República é apenas um exercício de curiosidade teórica, isso 
influenciará sobremaneira as práticas cotidianas, a interpretação de textos jurídicos, o exercício do poder público, o uso e o abuso de prerrogativas e privilégios por quem detém poder. E, nossas próprias definições dos limites entre uma e outra coisa, as prerrogativas do Estado sobre o cidadão e a forma como encaramos os espaços público e privado. Enfim, o sucesso ou o insucesso de nossa empreitada político-democrático dependerá da República que funda(re)mos.

Muitas práticas institucionais de hoje têm como origem a forma como essa mesma prática foi percebida ao longo do tempo em nossa sociedade e têm como pressuposto necessário o respectivo conceito de república. Por isso, refletir sobre a república que não construímos é buscar origens para que possamos reler/desconstituir certezas que naturalizam práticas antirrepublicanas. Apenas a título de exemplo, a exação tributária sentida por cada um de nós, dia a dia, está umbilicalmente atrelada à forma de república ou então da ausência dela: tributos são cobrados no Brasil de forma que invertem a lógica que deveria presidir o binômio arrecadação e contraprestação, é dizer, fundado basicamente no consumo e não na renda, nosso sistema tributário pune quem tem menor renda e, não apenas cobra menos, proporcionalmente, de quem tem mais, mas também por vezes, lhes cria isenções. ${ }^{1}$ De outro lado, altos salários de parte do funcionalismo público e de agentes políticos, ${ }^{2}$ além de facilidades de crédito para pessoas e empresas de alta renda fazem nosso sistema tributário não apenas manter como reforçar uma das sociedades mais desiguais do planeta.

Percebamos, então, que há relações de poder moldadas pela república e que se refletem no atual contexto. Mas não só a República molda o conceito que temos de institutos jurídicos, sociais e políticos, mas também as relações sociais moldam o conceito atual de República. Assim, a forma como se desenvolveram as relações sociais no Brasil é imperiosa para demarcar o conceito de república.

Não à toa a proclamação da República somente foi possível após a edição da Lei Áurea em 13 de Maio de 1888, possibilitando assim o desencadeamento dos fatos. Ora, impossível concebermos qualquer projeto republicano onde seres que deveriam ser livres e iguais em nossa comunidade política eram escravizados. Por outro lado, no entanto, sabemos bem que, ao lado

\footnotetext{
1 Sobre isso ver: http://www.valor.com.br/brasil/4172304/pessoas-mais-ricas-no-brasil-tem-658-do-totaldos-rendimentos-isentos, http://www1.folha.uol.com.br/paywall/signup.shtml?http://www1.folha.uol.com.br/mercado/2013/06/1 288441-tributo-sobre-consumo-e-o-verdadeiro-leao.shtml. Acesso em: 14 jun. 2020.

${ }^{2}$ VIANNA, Túlio. Julgando de barriga cheia. Jornal Estadão. São Paulo. 11 nov. 2012. Disponível em: http://alias.estadao.com.br/noticias/geral,julgando-de-barriga-cheia-imp-,958750. Acesso em: 14 jun. 2020.
} 
de ideais libertários, havia no movimento republicano elementos de revanchismo contra a própria abolição e de tomada do poder por aqueles que, até então, apenas mantinham relações com o mesmo. Qualquer simplificação, de um ou outro lado, é problemática e, pois, é preciso ter em mente essas contradições iniciais: fundamos a república para uma sociedade de livres e iguais ou apenas trocamos o comando de mãos? Substituímos uma Monarquia pela República ou por variados tipos de Oligarquias? Por outro lado, as mudanças se deram sempre "pelo alto"? 0 povo brasileiro sempre assistiu a tudo bestializado? Tornaremos a tais questões abaixo.

O que queremos marcar, desde já, é que o conceito de república depende efetivamente de nossas relações sociais e que o próprio conceito republicano vai sendo lido e relido ao sabor de nossas instituições e relações sociais. Nosso objetivo é investigar conceitos de República ao longo do projeto de redemocratização da Constituição de 1988 e como é influenciado e influencia em nossas práticas jurídicas, sociais e políticas.

Para tanto, utilizaremos dos métodos históricos para demonstrarmos como tal conceito vem se modificando e qual conceito é desenvolvido na Constituição de 1988. Não apenas teorizaremos historicamente práticas institucionais anteriores, mas buscaremos extrair 0 republicanismo em práticas institucionais atuais dos Poderes Executivo, Judiciário e Legislativo.

Como a República se afirma, ou se ausenta nas práticas institucionais na vigência da Constituição de 1988 é algo que dependerá, efetivamente, da criação ou não de uma cultura republicana ao longo do tempo institucional. Por isso, nossa análise deverá centrar atenção em períodos além da abertura democrática. Ademais, devemos analisar o papel das classes dominantes no cenário político e como a construção da república foi sempre feita a partir do que tais classes pensavam sobre o público.

Procuramos, assim, descortinar a opinião comum de que basta apenas a inserção da República no texto constitucional para que tenhamos práticas democráticas. A análise do conceito republicano em cada contexto histórico depende, à evidência, da forma como se emprega referido conceito nas práticas institucionais. 


\section{TEORIA DA HISTÓRIA: PROBLEMATIZANDO A CONSTRUÇÃO DOS}

\section{CONCEITOS A PARTIR DA NECESSIDADE DE ANÁLISE DO TEMPO COMO CONSTRUÇÃO SÓCIO-CULTURAL EM KOSELLECK}

Martin Heidegger foi quem possibilitou uma análise kairológica do tempo a partir de sua fenomenologia existencial demonstrada em Sein und Zeit. É de se destacar que a preocupação heideggeriana é com a noção ontológica de ser e não a noção ôntica do ser tradicional da metafísica ocidental, já que se confere um primado ontológico onde todas as ciências podem originar-se. $^{3}$

Heidegger, então, elabora um questionamento filosófico procurando algo mais do que um ente que se tem à mão. De um ente não pode haver outro ente, diz a filosofia heideggeriana. A pergunta pelo ente demonstra que há um perguntado, coisa que a ousía, a metafísica ocidental, sempre encobriu ao estudar apenas o ente como ser simplesmente dado (Vorhandenheit). 0 projeto filosófico heideggeriano é o estudo do ser, ser não enquanto ente, mas do ser que nós já sempre somos e que possui a possibilidade de questionar o ente, enfim, o ser existencial que tem na sua condição ôntico-ontológico a própria possibilidade de todas as ontologias. ${ }^{4}$ É o próprio Dasein que assume a tarefa fundamental de sempre ser as próprias condições a priori de possibilidade das ontologias das ciências ônticas. O ser-aí (Dasein), como ser existencial, apropria-se do mundo e é apropriado pelo mundo. É sempre um ser-no-mundo como constitutivo essencial do dasein, ocupando-se das coisas que the vêm ao encontro e que também determina seu modo de compreensão do mundo.$^{5}$

Desse modo, a existência do Dasein não pode ser confundida com o plano existentivo das coisas que simplesmente ocorrem. O existencial do ser-aí é sempre ek-sistere distinto do existentivo próprio do Vorhandenheit. É que sua existência é sempre um abrir para as possibilidades do mundo, é sempre um poder ser, algo que não é propriedade, no sentido de essência, mas de sempre estar aberto a possíveis maneiras de ser e nunca um ser-presente. Gianni Vattimo, por exemplo, explica bem a abertura do ser-aí: “Dizer que o homem existe não pode, pois, significar que o homem seja algo dado, porque aquilo que o homem tem de

\footnotetext{
${ }^{3}$ HEIDEGGER, Martin. Ser e tempo. 6. ed. Trad. Marcia de Sá Cavalcante Schuback. Petrópolis: Vozes, 2012, p.49.

${ }^{4}$ Ibidem, p.43.

${ }^{5}$ Ibidem, p.98-106.
} 
específico e que o distingue das coisas é justamente o fato de estar referido a possibilidades e, portanto, de não existir como realidade simplesmente-presente. 0 termo existência, no caso do homem, deve entender-se no sentido etimológico de ex-sistere, estar forma, ultrapassar a realidade simplesmente presente na direção de possibilidade". ${ }^{6}$ Este ser-no- mundo é a própria facticidade do aí.

A partir disso que o ser-aí é projetado em sua própria existência (Geworfenheit), enquanto ser jogado/lançado no mundo, sendo isto a condição de possibilidade de abertura do ser-aí, liberando a verdade, a finitude, a temporalidade e a historicidade. Sua indagação pela origem possibilita o encontro do vazio, da ausência de fundamento e, ao mesmo tempo, sua abertura finita para o mundo. A finitude e a abertura para o mundo faz com que ser aí controle e defina seu destino ${ }^{7}$, na medida em que a essência do ser é sua própria existência. Não há essência anterior que não seja a própria existência do homem.

O tempo, em Heidegger, é parte ontológica fundamental da existencialidade do dasein . ${ }^{8}$ Temporalidade é possibilidade que tem o dasein de assumir um sentido próprio e realizar uma decisão antecipadora de ser que se preocupa com a morte. Temporalidade, no entanto, não pode ser o sentido vulgar de tempo como futuro, passado e presente, como diz Heidegger.$^{9}$ Os conceitos de futuro, passado e presente são concepções impróprias de tempo. Impróprias no sentido de que são concepções típicas da metafísica da simples-presença. A temporalidade do ser-aí não pode ser uma sucessão de agoras, sem começo nem fim, já que é característica ontológica do Dasein ser-para-a-morte. Uma sucessão de agoras é apenas e tão somente a imagem do tempo vulgar que a metafísica entende como simples-presença. No caso da ontologia fundamental o caráter do tempo do dasein é de ekstases temporais ${ }^{10}$, cujo porvir assume papel preponderante.

O homem enquanto possibilidade, enquanto ser jogado possui as três características do tempo na qual em nenhuma delas é senhor. 0 porvir heideggeriano não significa que o ser-aí seja senhor dele, mas que, nas palavras de Ernildo Stein, ele bate contra a última possibilidade que é a impossibilidade de qualquer nova possibilidade.${ }^{11}$ Em outras palavras, José Reis explicita

\footnotetext{
${ }^{6}$ VATTIMO, Gianni. Introdução a Heidegger. Lisboa: Instituto Piaget, 2000, p.25.

${ }^{7}$ Heidegger bem explicita que "o ser-aí mesmo é enquanto jogado. Desdobra o seu ser no lance do ser que dispensa o destino e a ele torna dócil".

${ }^{8}$ HEIDEGGER, Martin. Ser e tempo. 6. ed. Trad. Marcia de Sá Cavalcante Schuback. Petrópolis: Vozes, 2012, p.303.

${ }_{9}$ Ibidem, p.411.

${ }^{10}$ Ibidem, p.413.

11 STEIN, Ernildo. Aproximações sobre hermenêutica. 2. ed. Porto Alegre: PUCRS, 2010, p.68.
} 
que o futuro implica no passado que também é implicado no presente.${ }^{12} \mathrm{E}$, sendo o presente, um acontecer de ekstases temporais, estão aí implicados no acontecer, no Ereignis, evento apropriante da compreensão do Dasein, tanto passado, presente e futuro em uma dimensão originária.

Como acontecer no mundo, enquanto ente lançado na facticidade da presença, o dasein é propriamente histórico, mas não histórico de um sentido de encadeamento de acontecimentos das coisas, mas um acontecer da temporalização própria de ser-no-mundo. Como afirma Heidegger, "a tese da historicidade da presença não afirma que é histórico o sujeito sem mundo mas, sim o ente que existe como ser-no-mundo. 0 acontecer da história é o acontecer de ser-nomundo. Em sua essência, historicidade da presença é historicidade de mundo que, baseada em sua temporalidade ekstática e horizontal, pertence à sua temporalização" . ${ }^{13}$

Partindo da temporalização heideggeriana, Koselleck procura refletir sobre o tempo histórico. Nessa medida, a datação exata constitui um passo importante para a organização e narração de eventos, mas não constitui a natureza do tempo histórico.${ }^{14} \mathrm{O}$ tempo histórico não é o cronológico que se baseia em medidas, números e leis da física e da astronomia, mas sim os tempos constituídos pela ação social e política de homens concretos que têm, cada qual, um ritmo próprio. Assim que se pode falar, em Koselleck, em muitos tempos históricos, sobrepostos uns aos outros.${ }^{15} \mathrm{~A}$ metodologia histórica proposta por Kosellecek dirige-se criticamente à forma anacrônica que a história do espírito (Geistesgeschichte) de corte hegeliano e da história das ideias (Ideengeschichte) de Dilthey lidavam com a contextualização de ideias e conceitos, transpondo do passado para a modernidade de forma descuidada o emprego de determinados léxicos, considerando-os imutáveis e não transformáveis ao longo do tempo. ${ }^{16}$

Koselleck elabora, então, um método e teoria da História dos Conceitos (Begriffsgeschichte). Uma história dos conceitos tem como método da história da terminologia

\footnotetext{
12 REIS, José. O tempo em Heidegger. Revista Filosófica de Coimbra, n. 28, 2005, p. 369-414. p. 378. Disponível em: https://digitalis-dsp.uc.pt/handle/10316.2/34187. Acesso em: 14 jun. 2020.

13 HEIDEGGER, Martin. Ser e tempo. 6. ed. Trad. Marcia de Sá Cavalcante Schuback. Petrópolis: Vozes, 2012, p. 480-481.

14 KOSELLECK, Reinhart. Futuro passado: contribuição à semântica dos tempos históricos. Trad. Wilma Patrícia Maas. Rio de Janeiro: Ed. Puc-Rio, 2006, p. 13.

15 Ibidem, p. 14.

16 JASMIN, Marcelo Gantus. História dos Conceitos e Teoria Política e Social: referências preliminares. Revista Brasileira de Ciências Sociais - vol. 20, $\mathrm{n}^{\circ}$ 57, fevereiro/2005, p. 27-38. p.32. DOI: https://doi.org/10.1590/S0102-69092005000100002. Disponível

em: https: / / www.scielo.br/scielo.php?pid=S0102-69092005000100002\&script=sci_abstract\&tlng=pt. Acesso em: 14 jun. 2020.
} 
política, filosófica e gramatical, mas não apenas cuida de textos como origem para, após sua exegese, retornar a ela. A história dos conceitos mantém uma relação complexa com a história social de tal modo que os conceitos fazem parte da terminologia política e social que é considerada relevante para o campo da experiência da história que se preocupa com as relações entre grupos e as formações sociais. ${ }^{17}$ Falando na metodologia da histórica conceitual, Koselleck explica que tal foi uma decorrência direta de tratar conjuntamente tempo e espaço, com a perspectiva sincrônica de análise. Para tanto, deve-se traduzir os termos utilizados para a compreensão atual, realizando sincronicidade e diacronicidade histórica. Após, em uma segunda etapa, os conceitos são separados de seu contexto situacional e seu significado estudado ao longo de uma sequência temporal, de tal modo que uma análise do conceito isoladamente se agrega a uma história do conceito. ${ }^{18}$

É importante, entretanto, salientar que, por mais que toda palavra carregue um conteúdo situacional, nem toda palavra pode se transformar em um conceito. Necessário, dentro da polissemia das palavras, que o conteúdo ali abarcado seja hipótese de certo nível de teorização e que contenha um caráter de reflexividade. ${ }^{19}$

Ao operacionalizar a metodologia da história dos conceitos sem dúvida alguma há um aumento no rendimento histórico e social da investigação. A lenta mudança estrutural de um significado permite ver como os conteúdos extralinguísticos foram compreendidos, possibilitando seu emprego nas estruturas sociais, fornecendo fortes indicadores para a história social. Com efeito, a partir da estratificação dos significados de um mesmo conceito, a metodologia proposta por Koselleck ultrapassa sincronia e diacronia, possibilitando simultaneidade da não simultaneidade que pode estar presente em um conceito, vale dizer, ao considerar que a metodologia da história parte do médio linguístico e que, por fundamento universal, cada significado lexical tem um alcance que ultrapassa a singularidade histórica referida, isso possibilita ao historiador reapropriar do conceito.

Em palavras sucintas, Julio Bentivoglio expressa que os conceitos não podem ser imutáveis, imodificáveis, mas sim dinâmicos, porquanto imersos na temporalidade e na

\footnotetext{
17 KOSELLECK, Reinhart. Futuro passado: contribuição à semântica dos tempos históricos. Trad. Wilma Patrícia Maas. Rio de Janeiro: Ed. Puc-Rio, 2006, p.97-98.

18 KOSELLECK, Reinhart. Futuro passado: contribuição à semântica dos tempos históricos. Trad. Wilma Patrícia Maas. Rio de Janeiro: Puc-Rio, 2006, 104-105.

19 Ibidem, p.135.
} 
linguagem: “Um conceito não é inalterável, não é um centro fixo e estável, mas deve ser entendido como um objeto imerso na temporalidade e na linguagem".$^{20}$

Desta sorte, Koselleck bem afirma que o estudo histórico a partir dos conceitos formula um importante parâmetro para se entender não só os aspectos sociais e culturais originários daquele significado, mas também entender como houve a apropriação moderna daquele conceito e em qual contextual é o mesmo aplicado.

É aqui que entra uma pragmática filosófica na teorização de Koselleck. Os conceitos em si mesmo não têm história, mas sua apropriação tem $\cdot{ }^{21}$ Ponto nuclear de sua teoria histórica é a resposta à questão do tempo histórico que Koselleck oferece com as noções de espaço de experiência e horizonte de expectativa. Através dessas categorias, Koselleck pretende firmar a própria noção antropológica do tempo considerada como condições possíveis para a história, uma vez que são condições humanas universais. Por isso mesmo, Koselleck considera-as como categorias meta-históricas.$^{22}$

Tais categorias remetem, pois, à própria temporalidade do homem e da história. Por experiência, entende o autor, o passado atual, aquela na qual acontecimentos foram incorporados e são lembrados, sejam eles de forma racional ou formas inconscientes de comportamento. Já a expectativa é o futuro presente, voltado sempre para o não experimentado, mas o previsto. Nas lições de Koselleck é na tensão que resulta das duas categorias que pode formar o tempo histórico. O espaço de experiência e o horizonte de expectativas são formas opostas que coordenam o passado e o futuro. Um futuro, por exemplo, nunca pode ser experimentado, se bem que é o espaço de experiência passado que abre o campo para as expectativas futuras. Dessa forma, constituem em uma diferença temporal, entrelaçando passado e futuro no hoje, capaz de permitir que o tempo histórico tenha a capacidade de se modificar. ${ }^{23}$

${ }^{20}$ BENTIVOGLIO, Julio. A história conceitual de Reinhart Koselleck. Dimensões, v. 24, 2010, p. 114-134. Disponível em: http://www.periodicos.ufes.br/dimensoes/article/download/2526/2022. Acesso em: 14 jun. 2020.

21 JASMIN, Marcelo Gantus. História dos Conceitos e Teoria Política e Social: referências preliminares. Revista Brasileira de Ciências Sociais - vol. 20, $\mathrm{n}^{\circ}$ 57, fevereiro/2005, p. 27-38, p.32. DOI: https://doi.org/10.1590/S0102-69092005000100002. Disponível em: https: / /www.scielo.br/scielo.php?pid=S0102-69092005000100002\&script=sci_abstract\&tlng=pt. Acesso em: 14 jun. 2020.

${ }^{22}$ KOSELLECK, Reinhart. Futuro passado: contribuição à semântica dos tempos históricos. Trad. Wilma Patrícia Maas. Rio de Janeiro: Ed. Puc-Rio, 2006, p. 307-308.

${ }^{23}$ Ibidem, p.313-314. 
Essa pequena digressão teórica formulada pelos meandros da teoria histórica de Koselleck permite-nos compreender melhor nosso objeto de estudo. Em primeiro lugar, a destruktion fenomenológica heideggeriana da noção de tempo legado pelo período medieval. Após, a interrelação entre passado e futuro através dos espaços de experiência e o horizonte de expectativas de Koselleck, permite-nos problematizar os conceitos jurídicos e evitar essencializações que não permitiriam enxergar o quadro atual do objeto.

Duas semânticas distintas no tempo e no espaço. Tempo que não pode ser medido historicamente pela cronologia, mesmo que tenhamos que voltar no passado para pensar alternativas para o presente. Kairós e não Chrónos deve ser retomado na atualidade, já que a história é ingovernável e o tempo não é retilíneo.

A história de nossa comunidade política bem ilustra a relação conflituosa que sempre tivemos com o ideal republicano. No ano de 1630, o historiador Frei Vicente Salvador já nos alertava que nos faltavam repúblicos, terra que, recém dominada, faltaria uma gestão voltada para a coisa pública e para os governados naquilo que, um dia, seria o Brasil. Nessa medida, importante considerarmos que a partir desse pressuposto teórico deve-se, para compreender o modelo republicano da Constituição de 1988, apreender com o espaço de experiência republicana nas constituições anteriores e projetarmos o horizonte de expectativas.

\section{REPÚBLICA E AUTORIDADE: A CONVIVÊNCIA CONFLITUOSA ENTRE A IDEIA REPUBLICANA E A CULTURA DE GOLPE}

Bem se sabe que a proclamação da república não foi um processo político livre de conflitos internos. Gestada dentro de uma monarquia desgastada pelas crises sociais, políticas e econômicas que assolavam o país com as rápidas transformações na sociedade, a república não nasce de um sentimento popular, de uma exigência democrática de instituições republicanas. É preciso ter presente que a República foi posta através de um golpe militar e conservador, em contraste direto com as discussões de liberais-políticos sobre a mesma que já ocorriam há anos no País. $\mathrm{O}$ dado do movimento republicano ter sido, no âmbito prático, um movimento de elites conservadoras aliadas a parcelas das Forças Armadas é algo que não se pode deixar de anotar. ${ }^{24}$

24 “Podemos dizer que no caso brasileiro os projetos republicanos (...) reivindicam a soberania, a concessão do poder absoluto à República, a um estado capaz de constituir um novo corpo político, baseado na vontade popular. $O$ ato político da Proclamação foi uma ação militar. A frase do jornalista 
Aliás, a partir daí irá se formar uma cultura política muito perigosa no Brasil, uma cultura do golpe, que é a dos militares como reserva ética e última tábua de salvação do povo, sempre prontos a reviravoltas no jogo político se tudo der errado.

Logo após a proclamação da república, ardentes defensores do ideal republicano efusivamente defendiam que a sociedade brasileira sempre respirava um sentimento republicano desde ao menos a Inconfidência Mineira. Emília Viotti sintetiza os defensores da interpretação republicana da República na medida em que eles:

consideram a Monarquia uma anomalia na América, onde só existem repúblicas. Repetindo as críticas feitas durante o Império ao Poder Moderador, afirmam que as liberdades foram cerceadas com grande prejuízo para a nação. Apontam as deficiências de D. Pedro como estadista. Criticam a centralização excessiva do governo monárquico, a vitaliciedade do Senado, a fraude eleitoral que possibilita ao governo vencer sempre as eleições, e consideram a República a solução natural para os problemas. A proclamação da República na opinião desses testemunhos foi a concretização de uma aspiração popular levada a efeito por um grupo de homens idealistas e corajosos que conseguiram integrar o país nas tendências do século. ${ }^{25}$

Bem verdade, no entanto, que há interpretações menos otimistas do que essas feitas pelos republicanos. Por exemplo, constatando tal ilusão, Oliveira Viana escreveu páginas clássicas sobre os motivos do desmoronamento do Império e acabou por concluir que:

\footnotetext{
"Não havia tal generalização de sentimento republicano, quando se deu a queda do Império. Por essa época, como o demonstramos, o sentimento mais generalizado não era o da crença na República, mas sim o de descrença nas instituições monárquicas, tais como existiam na Carta e eram praticadas nos centros do governo; mas, o certo é que essa descrença na Monarquia não importava necessariamente a existência do sentimento contrário, de fé nas instituições republicanas". ${ }^{26}$
}

\footnotetext{
republicano Aristides Lobo, em carta ao Diário Popular (18/11/89), retrata bem esta percepção: 'Por ora, a cor do governo é puramente militar, e deverá ser assim. 0 fato foi deles, deles só, porque a colaboração do civil foi quase nula. $O$ povo assistiu àquilo bestializado, atônito, surpreso, sem conhecer o que significava. Muitos acreditavam sinceramente estar vendo uma parada"' (CARVALHO, José Murilo de. Os bestializados: o Rio de Janeiro e a República que não foi. São Paulo: Companhia das Letras, 1987.) - e que segue praticamente como a única versão - se soma a esta outra, que mostra participação efetiva de pessoas no Rio de Janeiro. De outro lado, houve resistências, muitas, ao movimento e em apoio à Monarquia e aquele precisou de tempo - e muitas mortes - para se manter (OLIVEIRA, Lúcia Lippi. A questão nacional na Primeira República. São Paulo: Brasiliense; Brasília: CNPq, 1990, p. 88-89).

${ }_{25}$ COSTA, Emília Viotti da. Da Monarquia à República: momentos decisivos. 9. ed. São Paulo: Unesp, 2010, p.389.

${ }^{26}$ VIANA, Oliveira. 0 ocaso do Império. Brasília: Edições do Senado Federal, 2004, p.91.
} 
O movimento republicano tem um marco histórico bem definido: o dia 3 de Novembro de 1870 com a publicação de um manifesto assinada por 58 signatários, dissidentes do Partido Liberal em função da deposição do gabinete de Zacarias de Gois por Dom Pedro I em 1868 e a ascensão dos conservadores. ${ }^{27}$ Ora, o próprio movimento republicano é parasitário de um descontentamento a partir de uma atitude política do imperador. 0 manifesto foi veiculado pelo jornal $A$ República em seu primeiro número de 3 de Dezembro de 1870 . Em síntese, o manifesto publicado apenas criticava o “poder pessoal” de Dom Pedro I que seria contrário ao sentimento democrático da nação, bem como expunha a insatisfação com a política imperial a partir dos Anais do Parlamento e de artigos da imprensa.$^{28}$

A partir desse manifesto, o movimento republicano transformou-se em Partido Republicano Paulista (PRP), através da convenção de Itu de $1873 .{ }^{29} \mathrm{O}$ caminho de um movimento político até a efetiva proclamação da República dependeu de diversos fatores, dentre os quais longe está da influência política do próprio partido propagador. Em primeiro lugar, o Partido Republicano contou com a decadência das oligarquias tradicionais ligadas à terra, bem como a questão abolicionista, o processo de industrialização e a campanha pela federação. ${ }^{30}$ As classes rurais mais progressistas que defendiam a abolição na esperança de desenvolvimento econômico aliaram-se à classe média, desejosa de efetiva participação política nos negócios de Estado.

A essas questões sociais, somou-se também certa influência do positivismo filosófico de Augusto Comte. Republicanos à sua maneira, os positivistas acreditavam, com esteio em Augusto Comte, que o governo ideal seria uma república ditatorial. A Constituição Republicana não deveria ser oriunda de uma Assembleia Constituinte, mas de uma decretação do governo. Assim, o governo deveria ser constituído de uma oligarquia de sábios e filósofos, aptos a governarem a nação ${ }^{31}$. A grande influência do positivismo no Brasil, sem comparação com outros países da

\footnotetext{
${ }^{27}$ MENCK, José Theodoro Mascarenhas. A crise política de 1868 e a gênese do manifesto republicano de 1870. Cadernos ASLEGIS, n. 37, maio/agosto, 2009.

${ }^{28}$ VIANA, Oliveira. 0 ocaso do Império. Brasília: Edições do Senado Federal, 2004.p.87.

${ }^{29}$ GOMES, Laurentino. 1889. Rio de Janeiro: Globo, 2013. p. 157.

${ }^{30}$ COSTA, Emília Viotti da. Da Monarquia à República: momentos decisivos. 9. ed. São Paulo: Unesp, 2010. p.453.

${ }^{31}$ VIANA, Oliveira. 0 ocaso do Império. Brasília: Edições do Senado Federal, 2004.p.154. Não nos esqueçamos que o mote Ordem e Progresso é comtiano: “'O progresso exige ordem, sob a pena de cair na anarquia. E a ordem leva naturalmente ao progresso.' É como uma equação matemática, ou uma equação intelecto-filosófica fundamentada numa razão matemática empírico analítica" (SEYSSEL apud ZANELLA, ZANELLA, Camila. Análise Histórico Educacional do Positivismo Durante a Primeira República. XXVII Simpósio Nacional de História: conhecimento histórico e diálogo social. Natal, 22-26 de julho de 2013, p. 2. em:http://www.snh2013.anpuh.org/resources/anais/27/1371246624_ARQUIVO_artigoanpuh2013.pdf .
} 
América, leva a uma leitura conservadora do liberalismo: este se manifesta no âmbito econômico mas é, paradoxalmente, conservador quando aplicado à política ou a outras áreas . ${ }^{32}$

Os positivistas tiveram profundas influências na proclamação da república na medida em que eram o principal esteio filosófico ensinado nos colégios militares nos anos em que o ideal republicano vinha sendo debatido na esfera pública, principalmente a partir do debate pela mocidade militar ${ }^{33}$. Então, a conjugação dessas ideias filosóficas, cuja parte incluía a evolução da humanidade ${ }^{34}$ para um regime político republicano, com a adoção desse movimento filosófico por parte da mocidade militar, permitiu ser um elemento decisivo para a proclamação da República. Aliando, então, a mocidade militar e sua influência filosófica com a Questão militar, qual seja, o descontentamento dos militares participantes da Guerra do Paraguai - com o tratamento que lhes dispensava o governo - e o Partido Republicano que se aproveitou da situação, o golpe, então, foi tramado pelos militares.

Separando-se da camada dirigente, o exército busca apoio nos adversários do regime que, insatisfeitos com o rumo das questões sociais e econômicas, provinham da classe média e com os federalistas. $^{35} \mathrm{O}$ elo entre a sociedade civil e os militares seria a República, ao preço do afastamento do Império. Os republicanos não tinham o preconceito civilista e antimilitar de participação da força armada no mecanismo de governo, como por exemplo na crise de 1887 com Ouro Preto, Cotegipe, Silveira Martins, que repeliam a integração do governo com os militares. 0 elo seria realizado pelo cidadão de farda, como diz Raymundo Faoro, sendo o

reconhecimento, obstinadamente negado pela monarquia, da presença do oficial na política, não incidindo a disciplina senão no campo limitado da atividade profissional. 0 militar não deveria ser um membro segregado da sociedade, preso

2013, p. 2.). Acesso em: 15 jun. 2020.

32 LOPES, José R. de Lima. O Direito na História. 3. ed. SP: Atlas, 2011, p.341.

33 Laurentino Gomes dá um exemplo interessante. Quando José Bevilacqua, cearense e membro ativo das reuniões secretas do círculo militar, disse para sua mãe que iria morar em uma república de estudantes, a mesma se assustou. Conforme salienta, a simples menção a República era considerada perigosa, mormente no interior do Ceará em um país conservador. A república não passava de uma casa onde moravam estudantes, não por outra razão também denominada de república (GOMES, Laurentino. 1889. Rio de Janeiro: Globo, 2013, p. 157.p. 174).

${ }^{34}$ Faz parte do ideário positivista a ideia de "evolução" nas ciências e na/da humanidade: o uso de métodos rigorosos teria o poder de tirar a humanidade das trevas da Idade Média e levá-la para as Luzes da razão. Isso terá influências diretas sobre a forma como as ciências humanas e sociais concebem seus objetos de estudo. No caso do Direito, o Positivismo implica na purificação de qualquer questionamento que não pudesse ser subsumido à letra da lei.

35 STRECK, Lenio Luiz. Jurisdição constitucional e decisão jurídica. 3. ed. São Paulo: Revista dos Tribunais, 2013. p. 494. 
à obediência passiva, senão que se the abria a porta para trazer nas deliberações públicas sua voz, em nome de parcela fundamental do país. ${ }^{36}$

Falava o exército em nome da sociedade média, parcela da sociedade que também era excluída da política imperial. Criou-se no meio militar, aliás uma tendência que será decisiva para a criação da cultura de golpe, como mencionado acima, a ideia de que os cidadãos de farda eram, ao contrário dos cidadãos de casaca, incorruptíveis, puros, patriotas, detentores de uma mentalidade salvadora de nossa nação. ${ }^{37}$ Nessa medida, o papel decisivo para os militares efetivamente participarem da proclamação da República era a possibilidade de influência no governo.

O derradeiro golpe contra o antigo regime partiu do Marechal Deodoro da Fonseca que, conta-se, estava há cinco dias ainda indeciso de sua participação no movimento que culminaria na proclamação da República. Somente assentiu em dar ares republicanos ao movimento alguns dias antes, no dia 10 ou 11 de novembro, em que Benjamin Constant conseguiu convencê-lo a partir de sua rivalidade com Silveira Martins.

Ao contrário do pensamento de Paulo Bonavides, por exemplo, de que a intervenção militar foi o efeito e não a causa do 15 de novembro ${ }^{38}$, temos que o golpe de 15 de Novembro foi promovido, incentivado e efetivado nas fileiras militares. 0 próprio nascimento da república não é proveniente de um anseio popular, mas um movimento localizado de personalidades militares descontentes com o governo e de uma classe política ansiosa por uma participação política mais forte.

O Decreto n. 1 do Governo Provisório, editado por Marechal Deodoro da Fonseca e assinado também por Lobo, Ruy Barbosa, Quintino Bocaiuva, Benjamin Constant e Wandenkolk Correa, pretendia legitimar a proclamação da República submetendo-a ao sufrágio popular, conforme 0 art. $7^{\circ}$ do referido decreto. Daí já se percebe que o nascimento da república é obra de um movimento localizado e não generalizado na população nacional, o que é facilmente constatado pelas inúmeras tentativas de contragolpe e/ou de revoltas de cariz mais ou menos monarquista que se seguiram.

\footnotetext{
${ }^{36}$ FAORO, Raymundo. Os donos do poder: formação do patronato político brasileiro. 4. ed. São Paulo: Globo, 2008, p. 551.

37 VIANA, Oliveira. O ocaso do Império. Brasília: Edições do Senado Federal, 2004, p.118.

38 BONAVIDES, Paulo; AMARAL, Roberto. Textos políticos da história do Brasil - V. II: império e $2^{\circ}$ reinado (1840-1889). 3 ed. Brasília: Secretaria Especial de Editoração e Publicações do Senado Federal, 2002.
} 
Após aquele decreto vieram a dissolução de todos os partidos políticos em nível nacional, a formalização de uma Federação e a convocação de uma Assembleia Nacional Constituinte, isso para não se falar em atos de autoritarismo puro. Percebe-se que questões fundamentais para o novo regime foram estabelecidas unilateralmente por um governo provisório e militar. A extinção dos partidos políticos de âmbito nacional é um retrocesso democrático não compensado pela ampliação do direito de voto havida com a Constituição de 1891, ampliação esta relativa, pois se de um lado acabava com o critério de renda, por outro vedava o voto aos analfabetos sem que se cuidasse para que a educação fosse uma obrigação do Estado.

O desejo por uma Federação, isto é, por um aumento de autonomia às Províncias, se mostrou publicamente com o movimento republicano, como já adiantado ${ }^{39}$. No entanto, o que se seguiu à proclamação da República foi um aumento cada vez maior da centralização política. Ao invés da Federação ser criada para o fortalecimento dos Estados face ao poder central, sua criação se deu por mera decretação, como lembra Raul Machado Horta: “A Federação não surgiu de um pacto entre os Estados ou entre o Governo Provisório e os Estados. Impôs-se do alto, para acatamento e obediência de ato fundado na titularidade do poder armado. [...] Inexistindo pacto federativo anterior, o Congresso Constituinte [...] organizou, juridicamente, a Federação".40

Quanto à Assembleia Constituinte que daria origem à $1^{\text {a }}$ Constituição da República, esta foi marcada por intensa interferência do Executivo-militar. Nos primeiros meses da República havia fortes correntes que, seguindo a linha do federalismo norte-americano, propunham que a maior parte das leis deveria ser elaborada pelos Estados, e ao Legislativo Federal ficariam somente questões referentes a interesses gerais e à coexistência harmônica dos Estados. ${ }^{41} \mathrm{~A}$

\footnotetext{
${ }^{39}$ BONAVIDES, Paulo; AMARAL, Roberto. Textos políticos da história do Brasil - V. II: império e $2^{\circ}$ reinado (1840-1889). 3 ed. Brasília: Secretaria Especial de Editoração e Publicações do Senado Federal, 2002. p. 491-492.

Na verdade, segundo Ruy Barbosa, pelo menos desde os anos de 1830, os liberais, no Brasil, ostentavam a ideia de "Federação" - como resposta à manutenção da centralização decorrida da Constituição de 1822. A Confederação do Equador (1824) e a Insurreição Praieira (1848) proclamavam maior autonomia das Províncias e denunciavam descontentamento com a política de centralização de recursos na Corte ( BARBOSA, Ruy. Federação, Conservação. Jornal Diário de Notícias, 17.06.1889. In: BARBOSA, Ruy. Obras seletas. Rio de Janeiro: Fundação Biblioteca Nacional, v. VI. ., p. 116). Após o Manifesto de 1870, outro momento de afirmação da Federação foi o Congresso Liberal de 1888, que adotou um Programa Federal baseado na Constituição da Argentina e ainda duas tentativas do Deputado Joaquim Nabuco de aprovar, sem êxito, um projeto para alterar a Constituição, transformando o País numa Monarquia Federativa.

${ }^{40}$ HORTA, Raul Machado. Constituições Federais e pacto federativo. In: SAMPAIO, José Adércio Leite (coord.). Quinze anos de Constituição. Belo Horizonte: Del Rey, 2004.p. 165.

${ }^{41}$ NEQUETE, Lenine. O Poder Judiciário no Brasil a partir da independência: Império. V. II. Porto Alegre: Livraria Sulina, 1973, p.11.
} 
Assembleia Nacional Constituinte durante certo período também caminhou nesse sentido, com o apoio do Ministro Campos Salles. No entanto, o Governo Provisório impôs uma mudança de direção para garantir a centralização, vindo a provocar grandes discussões dentro da Constituinte. ${ }^{42}$ Uma das medidas foi a dissolução das Assembleias Provinciais e a atribuição de funções aos Governadores Provisórios dos Estados através do Decreto, de 20.11.1889.

A Constituição de 1891 consagra, pela primeira vez, e talvez única, em sua extensão, um Federalismo mais ou menos descentrado. Mesmo que as reivindicações federalistas mais extremas não hajam sido adotadas, quando comparada com as Constituições que se seguiram, percebe-se que, possivelmente, foi a Constituição que mais autonomia concedeu aos EstadosMembros: as legislações civil e penal eram nacionais, mas cada Estado teve oportunidade de prescrever normas processuais adaptadas às suas particularidades regionais. Dados da doutrina dão conta, no entanto, que a possibilidade de estabelecer normas de acordo com as particularidades locais foi pouco utilizada, sendo os Códigos Estaduais praticamente cópias do Regulamento $737 . .^{43}$

A real influência do constitucionalismo dos EUA sobre a República de 1891 parece se encontrar mais na transposição formal de algumas instituições do que na (re)apropriação profunda do que as mesmas significavam. É certo que a própria ideia de República, assim como o Presidencialismo e a Federação são ideias tomadas do exemplo norte-americano, há anos inspirando várias nações jovens na América e também velhas nações da Europa. No entanto, como já mostrado, a Federação por aqui não representava, nem de longe, a descentralização de funções e, logo, de poder, que a que havia nos EUA. E também, em menor grau, noutras Federações que the copiaram o formato, como a da Argentina.

Não apenas o poder estava centralizado no órgão central, a União, como também na figura do Presidente, uma vez que também aqui houve uma "adaptação" do modelo americano: por aqui o Presidente possuía, formal e informalmente, muito mais poderes para agir sem os necessários freios seja do Congresso seja do Judiciário. O uso indiscriminado de Decretos de Estado de Sítio e as prisões em massa durante tais períodos. Aliás, as prisões com motivação política já começavam antes da decretação e continuavam mesmo depois ${ }^{44}$ mostram várias

\footnotetext{
${ }^{42}$ BALEEIRO, Aliomar. Constituições Brasileiras: 1891. Brasília: Senado Federal e Ministério da Ciência e Tecnologia, 2001, p.29.

43 BERMUDES, Sérgio. Introdução ao Processo Civil. 4. ed. Rio de Janeiro: Forense, 2006, p.217.

${ }^{44}$ A ponto de HAMBLOCH afirmar: "Tão frequentemente foi aplicado o 'estado de sítio' pelos governos republicanos no Brasil que se tornou um fenômeno normal do regime presidencialista” (HAMBLOCH,
} 
coisas: fragilidade e, paradoxalmente (?) autoritarismo do regime que associamos à República; ausência de um Parlamento e de uma opinião pública fortes; ausência, ao fim e ao cabo de uma “res pública”.

Deodoro deixou o cargo em 23 de novembro de 1891 após pressão gerada por uma revolta militar. Vários políticos, jornalistas e militares que reivindicaram a realização de eleições presidenciais, foram presos pelo também Marechal Floriano Peixoto que viria a se tornar o segundo Presidente. Terminado o período de exceção, vários dos que haviam sido detidos antes, durante e após o Estado de Sítio então decretado, permaneciam sem julgamento por autoridade competente. Ruy Barbosa então impetrou o Habeas Corpus n. 300 em seu favor, pedido que foi denegado, sob a alegação de que o Tribunal era incompetente para lidar com questões políticas, pois, mesmo que envolvidos direitos individuais esta circunstância não habilita o Poder Judicial a intervir para nulificar as medidas de segurança decretadas pelo Presidente da República, visto ser impossível isolar esses direitos da questão política que os envolve e compreende ${ }^{45}$. Cite-se também o caso do Vapor Júpiter, quando Ruy Barbosa impetrou o HC. (coletivo) n. 406 e o HC. n. 410. Aqui, em razão do descumprimento por parte do Executivo de pedido de informações feito pelo STF, a ordem de soltura foi concedida. Ruy Barbosa ainda impetrou os HC. n. 412 e 415 em favor do Senador (e Almirante) Wandenkolk e outros oficiais do Exército ou Armada, envolvidos no caso do navio Júpiter. O STF, pressionado pelo Governo, é atribuída a Floriano a afirmação de que "os ministros do Supremo iriam precisar de ordens concessivas de habeas corpus caso viessem a libertar o Almirante Wandenkolk", decidiu, a 02.09.1893 não conceder a ordem. ${ }^{46}$

Logo após, Peixoto nomeou para o STF um médico e dois generais. No entanto, o Senado os rejeitou, por entender que apenas juristas poderiam ocupar o cargo. A reação do Presidente

Ernest. Sua majestade o presidente do Brasil - um estudo do Brasil constitucional (1889-1934). Brasília: Senado Federal, 2000.p. 105).

${ }^{45}$ Nesse HC. n. 300, Rui Barbosa defendeu ser competente o Supremo Tribunal Federal para apreciar os atos cometidos em razão do estado de sítio em virtude de que, se os atos que geraram a prisão eram políticos, ao mesmo tempo envolviam direitos individuais, logo, passíveis de serem apreciados judicialmente (cf. RODRIGUES, Lêda Boechat. História do Supremo Tribunal Federal. Rio de Janeiro: Civilização Brasileira, 1965.

p. 20-21). O Supremo Tribunal Federal, ao longo de sua existência, se valeu da doutrina das political questions para deixar de apreciar certas questões politicamente polêmicas. De fato, essa doutrina americana, a despeito de nunca haver sido bem definida no Brasil, esteve presente ao longo da história do STF (cf. KIMMINICH, Otto. Jurisdição constitucional e o princípio da divisão de poderes. Revista de Direito Público, n. 92, p. 17-33, out./dez. 1989. p. 26;SOUZA JR., Antônio Umberto. O Supremo Tribunal Federal e as questões políticas. Porto Alegre: Síntese, 2004, p. 68 et seq.).

46 RODRIGUES, Lêda Boechat. História do Supremo Tribunal Federal. Rio de Janeiro: Civilização Brasileira, 1965, p. 37 e ss. 
foi imediata e contínua: deixou de prover nomes para as vagas que iam surgindo, "praticamente inviabilizando o funcionamento do Tribunal". ${ }^{47}$

Ruy Barbosa, inicialmente defensor da República, percebeu pouco depois no que esta havia se transformado. Passou então, como visto, a lutar, nos Tribunais e fora deles, contra os desmandos dos Presidentes de sua época. Em 1898 publicou artigo no jornal A Imprensa condenando críticas do Presidente Prudente de Morais ao Supremo Tribunal Federal porque este concedera Habeas Corpus envolvendo prisões tidas por inconstitucionais em meio a um Estado de Sítio. A alegação do Presidente era de que a decisão do Tribunal havia sido tomada politicamente, sem a devida neutralidade por parte de seus membros.

A vinda de Presidentes civis não melhorou significativamente o quadro. Apenas para ficar com a questão do julgamento de atos dos Presidentes no STF, vale citar que no governo do Presidente Rodrigues Alves, “[...] a demora nos julgamentos era comum, fosse pela falta de quórum nas sessões, fosse para evitar enfrentamentos diretos com o Executivo". E, na presidência de Hermes da Fonseca, na decisão do HC. 3.527 (julgado em 1914), foram mantidas prisões decretadas durante Estado de Sítio, alegando o STF não poder declarar a inconstitucionalidade do Decreto. ${ }^{48} \mathrm{Em} \mathrm{1926}$, a Constituição sofre uma grande reforma, quando foram alterados vários de seus dispositivos. Tal reforma, de iniciativa do Presidente aconteceu durante um período de Estado de Sítio decretado pelo Presidente Arthur Bernardes, contrariando o que dispunha a Constituição vigente. ${ }^{49}$

Sob a Presidência do Presidente Afonso Pena foi aprovado o Decreto 1.641/1907, que permitia a expulsão de estrangeiros “indesejáveis": leia-se estrangeiros com ideais socialistas e anarquistas que chegaram com as grandes migrações do final do século XIX e início do XX ${ }^{50}$, essa medida foi depois agravada com o Decreto 2.741/1913, do Presidente Hermes da Fonseca. Movimentos contestadores como Canudos e Contestado foram duramente reprimidos.

47 CRUZ, Álvaro Ricardo de Souza. Breve histórico do Supremo Tribunal Federal e do controle de constitucionalidade brasileiro. In: SAMPAIO, José A. Leite (org.). Crise e desafios da Constituição. Belo Horizonte: Del Rey, 2004, p. 214.

${ }^{4}$ SALCEDO REPOLÊS, María Fernanda. Quem deve ser o Guardião da Constituição? Do poder moderador ao supremo tribunal federal. Belo Horizonte: Mandamentos, 2008, p. 105.

49 TORRES, Ana Paula Repolês. Reforma e crise constitucional: um ensaio de teoria da Constituição. 2005. Dissertação (Mestrado em Direito Constitucional) - Programa de Pós-Graduação em Direito da Faculdade de Direito da UFMG, Belo Horizonte, 2005, p. 205.

50 BONFÁ, Rogério L. Giampietro. "Com Lei ou Sem Lei”: as expulsões de estrangeiros na primeira república. Cadernos AEL, v. 14, n. 26, p. 183-214, 2009. 
Estes e outros casos mostram a fragilidade da ideia de "res publica", ou a ausência de sua compreensão, nos primeiros anos, uma vez que os postulados “libertários" com os quais foi reivindicada/fundada pouco se mostravam mesmo em comparação com o regime anterior.

Os mesmos militares que ajudaram na proclamação da República foram também responsáveis pela queda do regime de 1891. Na verdade, a revolução de 1930, apesar de ainda em certo sentido manter-se obscura, começa com o tenentismo de 1922. Foram revoltas de militares de nível intermediário, tenentes e capitães, contra a República e a oligarquia dominante. ${ }^{51} 0$ primeiro ato de rebeldia foi a revolta do Forte de Copacabana quando, em 05 de julho de 1922, 17 (dezessete) militares e um civil buscaram salvar a honra do exército em face das várias ofensas e represálias ao Clube Militar.

Após, o movimento tentou a derrubada do governo Arthur Bernardes em São Paulo, em 05 de julho de 1924, permanecendo na cidade de São Paulo até o dia 27 de Julho quando, expulsos, refugiaram-se no interior do Paraná à espera da oposição gaúcha liderada por Luís Carlos Prestes. Com o fito de chamar a atenção de outras localidades, Luís Carlos Prestes e seus comandados percorreram 24 mil quilômetros até fevereiro/março de 1927. Apesar de não haver uma proposta política bem definida, o tenentismo surgiu como reação às oligarquias, pretendiam ser representantes das classes médias.

O constitucionalismo da primeira república encontrava-se em vias de esgotamento. Patriarcalismo, coronelismo, a ausência de representatividade política, aliança entre a Igreja com os poderosos, subdesenvolvimento e a imobilismo social foram vícios que a República Velha institucionalizou e que o movimento de 1930 pretendia remediar. ${ }^{52}$ Políticos jovens, então, que ascenderam à sombra da velha oligarquia como Vargas, Osvaldo Aranha, Lindolfo Collor, João Neves, Maurício Cardoso no Rio Grande do Sul e Virgílio de Melo Franco e Francisco Campos de Minas Gerais tinham a ciência de que eventual ascensão política e a luta contra o sistema dependia da vontade de um estreito círculo de oligarcas. Houve, então, uma aproximação entre os jovens políticos e os tenentes.

Julio Prestes venceu a eleição de $1^{\circ}$ de Março de 1930 , sucedendo o presidente Washington Luís, quebrando a política do Café com Leite que exigia um presidente mineiro sucessor de um paulista. Então, formou-se a Aliança Liberal entre estados dissidentes, Rio

\footnotetext{
${ }^{51}$ FAUSTO, Boris. Historia do Brasil. $2^{\mathrm{a}}$ ed. São Paulo: Universidade de São Paulo, 1995, p. 307

52 BONAVIDES, Paulo; ANDRADE, Paes. História Constitucional do Brasil. 4. ed. Brasilia: OAB, 2002, p. 273.
} 
Grande do Sul, Minas Gerais e Paraíba. Em 03 de Outubro de 1930 a revolução estourou em Minas Gerais e no Rio Grande do Sul. Instalados em Ponta Grossa no Paraná, os militares sob o comando de Góis Monteiro e Getúlio Vargas planejavam um ataque às tropas que apoiavam Washington Luís em território paulista, a partir de Itararé. No entanto, tal ataque jamais chegou a acontecer. Os generais Tasso Fragoso, Mena Barreto e Leite de Castro pelo exército, bem como o Almirante Isaías Noronha, pela Marinha, depuseram o presidente da República e constituíram uma junta provisória de governo. Com a Revolução de 1930 o País permaneceu cerca de quatro anos num estado de para-legalidade, onde o Presidente da República, autodenominado Chefe do Governo Provisório, legislava indiscriminadamente.

Durante todo o período em que Getúlio Vargas governou o STF foi mantido em funcionamento, mesmo durante o “Estado Novo”. Graças às aposentadorias compulsórias de uns e nomeações de outros, o Governo conseguiu um Tribunal que the era favorável ${ }^{53}$. Sem embargo, a alteração nas normas sobre seu funcionamento foi uma constante. ${ }^{54}$

Entregue o poder a Getúlio Vargas, somente em 14 de Maio de 1932 a ditadura expediu o Decreto 21.402 convocando eleições para o dia 03 de Maio de 1933 para a Assembleia Constituinte. A demora na instalação da Assembleia Constituinte e a suspeita de que Vargas pretendia manter e expandir seus já ilimitados poderes fez com que eclodisse a luta constitucionalista de São Paulo contra o governo provisório de $1932 .{ }^{55}$ Através do Decreto 21.402/32, o Governo Provisório fixou a data para eleição da Assembleia Constituinte e nomeou uma comissão, chamada "Comissão do Itamaraty", para elaborar o Anteprojeto ${ }^{56}$. Somente em 16 de Novembro de 1933 instalou-se a Constituinte da $2^{\text {a }}$ República, dando ensejo à promulgação da Carta de 1934 que, como se vê, também é oriunda de um golpe militar e de uma imposição dos militares. A influência maior na Constituinte veio da ingerência do Governo Provisório: através do Decreto que instituía o Código Eleitoral, do Decreto que dispunha sobre a

\footnotetext{
${ }^{53} \mathrm{Ou}$, mais precisamente, submisso. Poucos dias após a instalação do governo provisório, o Presidente do STF veio a Getúlio Vargas transmitir-lhe os "melhores votos para o governo de fato, que se instalara" (BALEEIRO apud VIEIRA, Oscar Vilhena. Supremo Tribunal Federal: jurisprudência política. 2. ed. São Paulo: Malheiros, 2002, p. 129-130). Atitude semelhante teria o STF após o Golpe de 1964.

${ }^{54}$ BARACHO JÚNIOR, José Alfredo Oliveira. A interpretação dos Direitos Fundamentais na Suprema Corte dos EUA e no Supremo Tribunal Federal. In: SAMPAIO, José A. Leite (Org.). Jurisdição constitucional e os Direitos Fundamentais. Belo Horizonte: Del Rey, 2003, p. 333.

55 Bonavides defende o caráter de defesa dos princípios liberais do movimento (BONAVIDES, Paulo; ANDRADE, Paes. Historia Constitucional do Brasil. 4. ed. Brasilia: OAB, 2002, p. 274).

${ }^{56}$ Uma comissão de caráter pluralista dada a diversidade das concepções ideológicas de seus membros; o anteprojeto, tido como revolucionário, foi podado pela Constituinte. ( POLETTI, Ronaldo. Constituições Brasileiras: 1934. Brasília: Senado Federal e Ministério da Ciência e Tecnologia, 2001, p. 23-24).
} 
participação classista na Constituinte e até um outro Decreto que dispunha sobre seu Regimento Interno. Determinada a desenvolver um welfare state, a Constituição de 1934 por mais que pródiga em direitos sociais é um ato constituinte com sérios problemas: nasce sob certa ambiguidade, entre uma centralização administrativa a todas instâncias do corpo social e uma necessidade de representação política espelhadora de toda sociedade, à maneira do ideário de 1930.

Não por outra razão, a Constituição de 1934 teve vida curtíssima com a instalação da ditadura Getulista de 1937.

Mas como iniciar algo novo se sempre foram as oligarquias a comandar as propostas de mudança? Quando o debate se encerra apenas entre diferentes grupos de poder regionais e/ou entre oligarquias urbanas e rurais; quando todas as pressões populares foram durante rechaçadas/desmoralizadas e, quando não era mais possível manter uma certa configuração, a mudança é feita "pelo alto" para que nada seja mudado, então fica realmente difícil pensar em algo novo.

\section{OS PROBLEMAS DA TRANSIÇÃO: DO REGIME AUTORITÁRIO AO REGIME DEMOCRÁTICO.}

Por ter sido curto o período democrático da Constituição de 1946, logo interrompido por um golpe, suas práticas institucionais forneceram apenas pontuais influências para a construção de um ideal republicano no Brasil. Daí que optamos por não analisar o período político que vai da Constituição de 1946 até a longa noite de 31 de março e 01 de abril de 1964, até mesmo pelo fato de que as forças reacionárias já ensaiavam um golpe militar ainda durante o período democrático pós-1946.

O início da transição do regime que colocou o Brasil sob o jugo da ditadura militar também permite as percepções dos problemas que a República de 1988 enfrenta. Como não poderia deixar de ser, a República de 1964 começou com um golpe militar. Na real verdade, com uma conspiração político-militar que envolvia setores conservadores da sociedade, setores da elite econômica aliada a militares e setores da classe média buscaram, no caso de Minas Gerais, através do Instituto de Pesquisa e Estudos Sociais - IPES/MG, realizar um conjunto de ações político-ideológicos destinados a vincar uma reação generalizada contra o bloco nacionalistapopulista, procurando um domínio político-militar sobre a as classes baixas e também um efetivo 
comando sobre o aparelho estatal. ${ }^{57}$ Assentavam que o Brasil passava por uma crise de autoridade, de moralidade, em razão da corrupção, e, administrativa que facilitaria o propósito "comunista" de subversão da ordem e das instituições. Em Minas Gerais, no plano político contavam os "novos inconfidentes" com a estruturação do IPES/MG divididos em várias comissões destinadas a providenciar a luta contra o comunismo. No plano militar, os novos inconfidentes precisavam de apoio estrangeiro, destinado a conseguir armamentos, aptos a provisionar aquilo que seria um estado de beligerância. ${ }^{58}$

A conspiração político-militar transformou-se em golpe civil-militar através da Marcha com Deus pela Liberdade, uma série de eventos realizados pelas associações de senhoras católicas com o apoio de alas conservadoras da Igreja Católica, entre Março de 1964 a Junho 1964. ${ }^{59}$ Referida manifestação demonstra considerável apoio social dado por setores da população às pretensões golpistas do movimento de 1964, aliado ainda a um descontentamento generalizado sobre o discurso do Presidente João Goultart que pretendia realizar as chamadas Reformas de Base, instituindo o Imposto sobre Fortuna, realizando a Reforma Agrária, e outras reformas administrativas. Quinhentas mil pessoas arrogaram-se em defensores da liberdade e da Constituição ${ }^{60}$, possibilitando o apoio social necessário para que os militares se considerassem no direito de proteger o Brasil contra a ameaça vermelha.

Com o apoio do Governador de Minas Gerais Magalhães Pinto ${ }^{61}$, o general Olímpio Mourão Filho desloca as tropas de Juiz de Fora/MG para a cidade do Rio de Janeiro em 31 de Março de 1964. Em $1^{\circ}$ de Abril de 1964, João Goulart para evitar derramamento de sangue voou para Brasília e de lá para Porto Alegre buscava se refugiar no Uruguai. Na noite do dia $1^{\circ}$ de Abril, o Presidente do Senado Federal declarou vago o cargo de Presidente da República, mas não convocou novas eleições, já que o poder estaria não mais nas mãos da sociedade, mas dos militares.

Em 09 de Abril de 1964 a “revolução" edita o Ato Institucional número 1 assinado pela junta militar que manteria, formalmente, a higidez da Constituição de 1946. Logo no preâmbulo

\footnotetext{
${ }^{57}$ STARLING, Heloisa Maria Murgel. Os senhores das gerais: os novos inconfidentes e o golpe de 1964. 4. ed. Petropólis: Vozes, 1986, p. 47.

58 STARLING, Heloisa Maria Murgel. Os senhores das gerais: os novos inconfidentes e o golpe de 1964. 4. ed. Petropólis: Vozes, 1986, p.48.

${ }^{59}$ FAUSTO, Boris. Historia do Brasil. $2^{\text {a }}$ ed. São Paulo: Universidade de São Paulo, 1995, p.460.

60 Basta ver, por exemplo, o editorial da Folha de São Paulo de 20 de Março de 1964 noticiando o acontecimento.

61 O Mineirão, estranhamente, o maior estádio de Belo Horizonte, ainda hoje leva seu nome em homenagem aos seus préstimos realizados durante a Revolução Militar.
} 
do dito ato legislativo, a junta militar disciplina que: "A revolução vitoriosa se investe no exercício do Poder Constituinte. Este se manifesta pela eleição popular ou pela revolução. Esta é a forma mais expressiva e mais radical do Poder Constituinte. Assim, a revolução vitoriosa, como o Poder Constituinte, se legitima por si mesma. Ela destitui o governo anterior e tem a capacidade de constituir o novo governo". Esvai-se, assim, o período democrático vivido sob o regime da Constituição de 1946.

O caminho escolhido pelos militares foi o fortalecimento e a concentração de todo o poder nas mãos do Executivo. ${ }^{62}$ Vale dizer, em que pese manter o funcionamento do Congresso Nacional, o próprio Ato Institucional número 1 previu a possibilidade de aprovação tácita, após o decurso do prazo de trinta dias, de projetos de lei enviados pelo Poder Executivo (art. $4^{\circ}$ ), bem como a suspensão das garantias de vitaliciedade e estabilidade (art. $7^{\circ}$ ).

Há um rígido esforço pelo governo militar no sentido de conferir aparências de legalidade às medidas tomadas pela Junta Militar, uma vez que convivem no mesmo espaço-temporal da Constituição de 1946 e medidas autoritárias buscando legitimar o poder político oriundo do golpe militar. ${ }^{63}$ Os atos institucionais posteriores também excluíam matérias da apreciação judicial, bem como previram a extinção dos partidos políticos em funcionamento já através do Ato Institucional n. 2. O Ato Institucional n. 3 estende o princípio da eleição indireta do Presidente e Vice-Presidente da República para os Governadores e vice-governadores. E o Ato Institucional $n$. 4 finalmente convoca o Congresso Nacional para discutir e votar um novo texto constitucional. 0 cronograma para discussão e votação do projeto de uma nova Constituição era de 12 de Dezembro de 1966 a 24 de Janeiro de 1967. Evidentemente, um período muito curto para discutir e deliberar, democraticamente, uma Constituição. 0 calendário foi cumprido rigorosamente. Os parlamentares, além de não estarem investidos na condição de constituintes, estavam também ameaçados pelos atos institucionais. Nessa medida, o que houve foi, como bem lembra Paulo Bonavides, uma farsa constituinte. ${ }^{64}$

Os dispositivos da Constituição de 1967 parecem conviver bem com a ideia de regime representativo, liberdade, igualdade e direitos individuais e uma prática social e institucional absolutamente contrária. Não sem razão, por exemplo, levam alguns juristas como Alcides de $M$. Lima a afirmar que a Constituição Federal de 1967 aperfeiçoou muitas instituições e retrocedeu

\footnotetext{
62 BONAVIDES, Paulo; ANDRADE, Paes. Historia Constitucional do Brasil. 4. ed. Brasilia: OAB, 2002 , p.434. 63 PEREIRA, Anthony. Ditadura e repressão: o autoritarismo e o Estado de Direito no Brasil, no Chile e na Argentina. São Paulo: Paz e Terra, 2010.

64 BONAVIDES, Paulo; ANDRADE, Paes. Historia Constitucional do Brasil. 4. ed. Brasilia: OAB, 2002 , p.436.
} 
em poucas, ${ }^{65}$ tal era o clima de ambiguidade que residia não só na sociedade, mas também nos próprios especialistas.

Classificando-se a Constituição de acordo com a concordância das normas constitucionais com a realidade do processo de poder, a Constituição de 1967 constitui um perfeito exemplo de Constituição semântica, isto é, aquela em que seu caráter normativo, apesar de existente, conforma-se à vontade dos detentores do poder. Ao invés da limitação do poder, a Constituição semântica serve como meio para estabilizar e eternizar os detentores do poder. ${ }^{66}$ Basta ver, por exemplo, a coexistência de normas garantidoras de direitos individuais com as práticas políticorepressivas do Tribunal de Segurança Nacional fundamentadas na Lei definidoras de crimes contra a ordem política e social - Lei de Segurança Nacional. Criado pela Lei 244 de 11 de Setembro de 1936, ao Tribunal de Segurança Nacional incumbia perseguir os dissidentes políticos, condenando-os nos delitos políticos capitulados pela Lei de Segurança Nacional sem qualquer garantia de contraditório, de ampla defesa, do devido processo legal, sendo apenas a encenação de uma peça cujo protagonista restava sempre sendo condenado.$^{67}$

A esperança de efetividade e democracia resta sepultada pela promulgação do Al 5 em 13 de Dezembro de 1968. Referido ato institucional foi baixado por Costa e Silva e, basicamente, fechou o Congresso Nacional, estabeleceu a possibilidade do Presidente da República decretar a intervenção federal, fora dos casos previstos na Constituição, suspender os direitos políticos de quaisquer cidadãos pelo prazo de 10 (dez) anos, além da possibilidade de decretação de Estado de Sítio e defesa com a suspensão das garantias individuais e, ainda, a exclusão da apreciação jurisdicional dos atos praticados com base no referido Ato Institucional. 0 Al 5 e, posteriormente, a Emenda Constitucional n.1/69, mergulharam o país na ditadura mais profunda e reverberam a cultura de golpe político-militar. Aposentando servidores públicos, reformando militares, demitindo sumariamente, cassando prefeitos, deputados federais e estaduais, ministros do STF, proibindo a liberdade de imprensa, a livre comunicação de ideias através da censura de obras musicais, artísticas e culturais, aliando-se à perseguição bélica contra os dissidentes, o Brasil viveu sob um rígido aparato político.

A transição para a abertura democrática é marcada por ambiguidades, violência, opressão e, sobretudo, privilégios dos defensores do regime. 0 primeiro passo do regime militar

\footnotetext{
65 LIMA, Alcides de Mendonça. As novidades da constituição federal de 1967, segundo a emenda n. 1 , de 1969. São Paulo: Juriscredi, 1971.

66 LOEWENSTEIN, Karl. Teoria de la Constitución. Barcelona: Ariel, 1978, p.66.

${ }^{67}$ CATTONI DE OLIVEIRA, Marcelo Andrade; SIQUEIRA, Gustavo Silveira. Pequeno Ensaio sobre a Injustiça: memórias secas de um tribunal de segurança nacional. Seqüência, n. 61, p. 111-125, dez. 2010.
} 
é garantir a impunidade dos seus crimes. É tentar apagar o passado, deixar sem vestígios os crimes perpetrados contra os dissidentes. Nada melhor, então, do que os próprios beneficiários imporem seu propósito de esquecimento. Com este espeque veio a lume a Lei 6.683/79 que buscava a um só tempo, impor o esquecimento e praticar uma espécie de transição por negociação, uma transição como permanência ${ }^{68}$ materializada naquela lei, que deu margem de interpretação equivocada de esquecimento para os dois lados. ${ }^{69}$

A falta de informações a respeito do processo de transição leva, por exemplo, a interpretações de que a Lei da Anistia teria sido objeto de um acordo político entre o regime e a sociedade civil, um acordo de transição conciliada política, como disse o Min. Eros Grau, de suaves compromissos. Isso porque foram todos absolvidos, uns absolvendo-se a si mesmos. Diante disso, o Min. Eros Grau entende que o processo histórico demonstraria a necessidade de que a anistia fosse ampla e irrestrita, abrangendo também os crimes praticados por agentes do Estado. ${ }^{70}$

Como bem salientado pelo Emílio Peluso, a questão é que a sociedade travou uma batalha pela anistia e a Lei $6.683 / 79$, como aliásnão pode deixar de ser em períodos ditatoriais, da forma como foi promulgada, representou uma imposição do regime. Veja-se, por exemplo, que o trabalho da Comissão Mista de Anistia foi fortemente controlada pelo governo, já que a maioria dos membros pertencia à ARENA. Ademais, nos trabalhos da Comissão de Anistia vozes já se levantavam contra a expressão crime conexo ao político e a impunidade que, de certo, adviria de tal expressão aos agentes políticos do Estado, o que acabou sendo consolidado pelo STF na ADPF 153 ao confirmar a constitucionalidade da Lei de Anistia, inviabilizando, assim,

${ }^{68}$ CATTONI DE OLIVEIRA, Marcelo Andrade. Democracia sem espera e processo de constitucionalização: uma crítica aos discursos oficiais sobre a chamada transição política brasileira. In: CATTONI DE OLIVEIRA, Marcelo Andrade (org.). Constitucionalismo e História do Direito. Belo Horizonte: Pergamum, 2011, p.212.

${ }^{69}$ Como ressalta Paulo Abrão e Marcelo D. Torelly, o processo de Anistia no Brasil foi um movimento de luta da sociedade contra o regime. Dois aspectos merecem ser mencionados que cuidará de interpretar adequadamente a análise da Lei de Anistia. 0 primeiro aspecto centra-se no fato de que a anistia devia se referir, originalmente, aos presos políticos. A abrangência da lei da Anistia para os crimes de tortura cometidos pelos Agentes de Estado jamais foi objeto de consideração de possibilidade da sociedade civil, já que os crimes de Tortura não eram objeto de conhecimento da sociedade. O segundo aspecto está em que a classe trabalhadora foi a principal oposicionista do regime militar, intensificando-se as greves a partir do momento da "negociação" da Lei da Anistia (ABRÃO, Paulo; TORELLY, Marcelo D. Justiça de Transição no Brasil: a dimensão da reparação. Revista Anistia Política e Justiça de Transição, Ministério da Justiça, n. 3, 2010, p. 113).

${ }^{70}$ MEYER, Emílio Peluso Neder. Ditadura e responsabilização: elementos para uma justiça de transição no Brasil. Belo Horizonte: Arraes Editores, 2012. 
eventuais processos de responsabilização dos agentes torturadores que trabalharam para 0 regime militar $^{71}$.

$\mathrm{Na}$ verdade, invertendo a lição de Eros Grau, o que ele chama de "suaves compromissos" foi propriamente a abertura democrática. Após ter garantida a irresponsabilidade e impunidade pelos crimes cometidos durante o período de governo, o regime militar ainda demoraria para completar o processo de transição, tentando obter o controle do próprio processo de abertura.

0 ato "revolucionário" reteve o Poder Constituinte. A edição do Ato Institucional n. 1, com a deposição do governo eleito e a promessa de futura convocação do Poder Constituinte, apenas fez colocar a legitimidade em um estado de profunda sonolência. Houve o diferimento da legitimidade $^{72}$, da instituição de um Estado legítimo, que permitiu a uma elite dirigente o controle sobre o país. Como devolver ou recuperar a legitimidade perdida? De certo, o caminho em prol da soberania popular não é uma estrada que se persegue sem lutas, no plano das abstrações, jurídicas ou políticas. O Poder Constituinte e a luta pela legitimidade é uma luta social desenvolvida no seio da sociedade civil que clama pela participação nos círculos restritos da classe política. O movimento deve partir daqueles que necessitam, ou seja, dos atores que são excluídos da participação na gerência governamental. Nada mais enganoso do que pensar que o Poder Constituinte é consequência da falência de um modelo de Estado.

Em verdade, aqueles que creem que a constituinte somente advém de um colapso de poder pretendem dissimular a sustentação do status quo, já que exprime um descrédito na opinião pública ávida pela implantação de valores democráticos. Ora, como nos lembrou Raymundo Faoro, antes de 1988, o que havia de liberal e democrático advinha das constituintes

\footnotetext{
71 STF, ADPF 153/DF, rel. Min. Eros Grau, j. 29/04/2010. Um caso paradigmático do que Boaventura chama de "contrarrevolução jurídica" (S SANTOS, Boaventura de Sousa. Para uma revolução democrática da justiça. $3^{a}$ ed. São Paulo: Cortez, 2011.). Sobre o tema é preciso lembrar que, semanas após essa decisão veio uma condenação do Brasil perante a Corte Interamericana de Direitos Humanos (CIDH) no caso "Gomes Lund (e outros) vs. República Federativa do Brasil", em que a Corte questiona a conformidade da Lei de Anistia brasileira - no que toca à "auto-anistia" -, inclusive fazendo críticas à decisão do STF referida acima. Após essa decisão criou-se um impasse, uma vez que ela caminha em um sentido e a do STF noutro ( MEYER, Emílio Peluso Neder. Ditadura e responsabilização: elementos para uma justiça de transição no Brasil. Belo Horizonte: Arraes Editores, 2012.). Em razão da decisão da CIDH foram opostos Embargos de Declaração (ainda pendentes de julgamento) e também interposta a ADPF. n. 320 - em ambos o que se pede é que o STF reveja sua decisão tendo em vista o firmado por aquela Corte Internacional.

72 É através da obra, do texto do Poder Constituinte, texto este ao mesmo tempo constatativo e performativo, com a assinatura que é ela própria produtora e garante de sua própria obra já que não há assinante antes de sua própria obra (DERRIDA, Jacques. Declarations of Independence. New Political Science Review. 1986). Nessa medida, veja-se que os produtores e garantes do regime de 1964, assinantes do Ato Institucional n. 1 é a junta militar.
} 
realizadas em 1823, 1891, 1932 e 1945 e o que há de estamental e elitista veio de outorgas, emendas e atos de força, ainda que "nunca o Poder Constituinte tenha conseguido nas suas quatros tentativas vencer o aparelhamento de poder, firmemente ancorado ao patrimonialismo de Estado, mas essas investidas foram as únicas que arvoraram a insígnia da luta, liberando energias parcialmente frustradas". ${ }^{73}$

O movimento por uma Constituinte teve em seu caminho a leitura da Carta aos Brasileiros realizada pelo jurista e professor Goffredo Teles Júnior em 08 de Agosto de 1977 nas Arcadas do Largo do São Francisco, conclamando a restauração da legitimidade do poder através do Poder Constituinte.

Após, em 1980, a Ordem dos Advogados do Brasil celebrou um Congresso em Manaus destinado a convocar uma Assembleia Nacional Constituinte. 0 movimento, então, espalhou-se contando com a adesão das organizações civis, órgãos de imprensa, estudantes, advogados, professores, trabalhadores e adquiriu a força popular necessária para a reinvindicação em torno da causa.

Em 1983 os partidos políticos aderem à causa popular. PT, PMDB, PDT, CUT manifestaram-se em São Paulo, ainda sem tanta participação popular. O presidente do PMDB, Ulysses Guimarães, adota algumas iniciativas. Dentre tais, o apoio do Governador de São Paulo, Franco Montoro, permitiu um comício realizado em 27 de janeiro na Praça da Sé que contou com milhares de pessoas. Indo além das organizações partidárias, o “Diretas-Já” ganhou o entusiasmo popular com milhões aderindo o movimento político.

Para alcançar o objetivo das eleições diretas, no entanto, era preciso o voto de $2 / 3$ dos membros do Congresso, inteiramente dominado pelo PDS. Proposta pelo Deputado Dante de Oliveira, a Emenda que levou seu nome não conseguiu a aprovação necessária na Câmara dos Deputados, frustrando a expectativa popular. A questão, então, ficou para o Colégio Eleitoral.

As eleições de 1985 do Colégio Eleitoral ficaram marcadas pela disputa entre, de um lado, Paulo Maluf, candidato pelo partido do governo (PDS) e, por outro, Tancredo Neves e José Sarney, candidatos a presidente e vice pelo PMDB e partidos oposicionistas. Com a dissidência do PDS, Tancredo Neves conquistou a esmagadora maioria dos votos do colégio eleitoral. Por problemas de saúde ele foi internado antes de tomar posse no cargo, marcada para o dia 15 de março de 1985. José Sarney, então, substitui-o, no que se acreditava pudesse ser uma situação transitória. Tancredo Neves vem a falecer em 21 de abril e José Sarney propõe ao Congresso

${ }^{73}$ FAORO, Raymundo. A república inacabada. São Paulo: Globo, 2007, p.257. 
Nacional a convocação de uma Assembleia Nacional Constituinte. Essa iniciativa resultou na Emenda Constitucional n. 26 de 27 de novembro de 1985. Um pouco antes de aprovada a Emenda o Presidente, através do Decreto 91.450/1985, constituiu uma comissão de estudos constitucionais provisórios, denominada de Comissão Afonso Arinos por ter Afonso Arinos de Melo Franco como seu presidente. Essa comissão também conhecida como de notáveis, teve a participação de 50 (cinquenta) membros, juristas reconhecidos e com notória experiência tais como José Afonso da Silva, Miguel Reale, Raul Machado Horta, dentre outros. Referida comissão apresentou um Anteprojeto Constitucional que, no entanto, não foi enviado à Assembleia Nacional Constituinte pelo presidente José Sarney, mas sim para o Ministro da Justiça e, pois, foi arquivado e servindo apenas de inspiração aos trabalhos da constituinte.

A EC. 26/85 determinou que, a partir de $1^{\circ}$ de fevereiro de 1987, Câmara dos Deputados e Senado Federal reunir-se-iam em Assembleia Nacional Constituinte. A instalação da Assembleia seria presidida pelo Presidente do Supremo Tribunal Federal que dirigiria a eleição de seu Presidente (art. $2^{\circ}$ da EC 26/85). A Constituição seria promulgada, depois de dois turnos de discussão e votação, pela maioria absoluta dos membros da Assembleia Nacional Constituinte (art. $3^{\circ}$ da EC 26/85).

Ora, não se deve esquecer que o momento constituinte é de pura violência rompedora e fundadora $^{74}$, é derivado de uma ambiência de transformação em que o direito precisa dar resposta e restabelecer o crédito nas instituições constitucionais. Assim era o ambiente do início dos anos 1980. Um apelo a começar de novo, de união de espíritos para refundar e recomeçar, rompendo com a sistematicidade constitucional anterior. Uma constituinte cujo produto foi elaborado artigo por artigo, com várias audiências públicas e intensa participação popular através de emendas populares. Daí o caráter verdadeiramente constituinte de $1987 .{ }^{75}$

\footnotetext{
${ }^{74}$ DERRIDA, Jacques. Força de lei - o "fundamento místico da autoridade". São Paulo: Martins Fontes, 2007.

${ }^{75}$ SAMPAIO, José Adércio Leite. Teoria e prática do Poder Constituinte. Como legitimar ou desconstruir 1998- 15 anos depois. In: SAMPAIO, José Adercio Leite (org.) Quinze anos de Constituição. Belo Horizonte: Del rey, 2004, p.30-31.
} 


\section{REPÚBLICA APERFEIÇOADA OU REPÚBLICA INACABADA? O TEXTO CONSTITUCIONAL E AS TENTATIVAS DE IMPLEMENTAÇÃO DO PROJETO REPUBLICANO}

Será, realmente, que o texto constitucional de 1988 conseguiu abrir a fechada casa de máquinas da Constituição ${ }^{76}$ ? Houve avanços na nossa inacabada república? Quais foram os avanços decorrentes do projeto constitucional de 1988? E quais os problemas enfrentados na vigência da Constituição até o momento?

Inegável, pois, que o texto constitucional de 1988 aposta na democratização como forma de possibilitar a efetivação de um projeto republicano. O receio com as crises políticas que possibilitavam a implementação de projetos ditatoriais, bem como a adoção de mecanismos que impossibilitavam a participação popular durante os regimes antidemocráticos, fizeram com que o Constituinte promovesse a possibilidade de participação popular.

Logo no intróito do texto constitucional reafirma-se a adoção de um Estado Democrático de Direito (art. $\left.1^{\circ}, \mathrm{CF} / 88\right)$. Em que sentido, portanto, pode se conciliar a República com o Estado Democrático de Direito? É função do Estado Democrático de Direito refundar a legitimação do poder internamente. Com força performativa, o texto constitucional implica sempre um processo de construção de uma sociedade de membros livres e iguais, de forma que não apenas a Constituição, como a própria democracia e a República, são projetos que precisam se atualizar e se realizar no tempo. Toda Constituição é um projeto cuja legitimidade se projeta para o futuro, em um processo de constantes inclusões de novos direitos e de novos sujeitos de direito.

É preciso entender, portanto, que o texto constitucional não funda uma comunidade de membros que compartilham, sob o signo da ideia comunitarista, uma identidade comum, um compromisso com certos ideais de projeto de vida. ${ }^{77}$ Deve-se manter em aberto o sentido da autodeterminação nacional. ${ }^{78}$ Isto é, em um mundo plural, onde predominam várias concepções de mundo, cosmovisões éticas, religiosas e culturais, o único sentido possível da democracia é institucionalizar a formação da vontade pública, de tal forma que os instrumentos estejam

\footnotetext{
${ }^{76}$ GARGARELLA, Roberto. La sala de máquinas de la Constitución: dois siglos de constitucionalismo en América Latina (1810 -2010). Buenos Aires: Katz, 2014.

77 CITTADINO, Gisele. Pluralismo, direito e justiça distributiva: elementos de filosofia constitucional contemporânea. $3^{\mathrm{a}}$ ed. Rio de Janeiro: Lumen Juris, 2004, p. 162.

${ }^{78}$ HABERMAS. Jürgen. A inclusão do outro: estudos de teoria política. São Paulo: Loyola, 2002, p.159.
} 
receptivos a serem permeados pelos valores, temas, contribuições e argumentos sugeridos pela comunidade política. ${ }^{79}$

A legitimidade advém, então, da coesão entre a participação política e o exercício das liberdades subjetivas, isto é, nos dizeres de Habermas, uma co-originalidade entre a autonomia privada e autonomia pública, de tal forma que a vontade pública se veja livre de coerções e o espaço público seja normatizado e amplamente inclusivo. ${ }^{80}$ Isto é, sob o paradigma procedimentalista da democracia e do direito, direciona-se a sociedade para um futuro estratégico de democratização. ${ }^{81}$

O jogo de interpretação da Constituição, assim, não pode ser cerrado apenas a especialistas. Toda a comunidade política deve participar desse processo de construção de uma comunidade política e desenvolvimento de um Estado Democrático de Direito. Aqueles que se encontram implicados no processo de construção da sociedade, também são efetivos intérpretes .$^{82}$ A institucionalização da formação da vontade política e a possibilidade dos cidadãos construírem o projeto constitucional contaram com o resgate de instrumentos da democracia direta no art. 14, quais sejam, o plebiscito, referendo e a iniciativa popular de projeto de lei, como esperança de consolidação de um projeto democrático maduro. Muito embora o próprio texto constitucional faça a utilização dos instrumentos da democracia direta institucional depender da vontade legislativa e da interposição do legislador, a efetiva participação popular nos meandros do poder, inclusive de forma não institucional, é essencial para a concretização do regime democrático, razão pela qual eventual regulamentação legislativa não pode criar limites inexistentes para os institutos.

A primeira participação popular no processo de tomada de decisão no período democrático foi o plebiscito previsto já no texto constitucional pelo art. $2^{\circ}$ do Ato das Disposições Constitucionais Transitórias. A Emenda Constitucional n. 2 modificou a data de realização do Plebiscito para o dia 21 de Abril de 1993. Tal convocação, realizada pelo próprio

\footnotetext{
79 HABERMAS, Jürgen. Soberania popular como procedimento: um conceito normativo de espaço público. Novos Estudos Cebrap, n² 26, março de 1990, p. 100-113. p. 110-111.

${ }^{80}$ HABERMAS, Jürgen. Facticidad y Validez: sobre el derecho y el Estado democrático de derecho em términos de teoría del discurso. Trad. Manuel Jimenez Redondo. 6. ed. Madri: Trotta, 2010, p. 610.

${ }^{81}$ ARATO, Andrew. Procedural law and civil society: interpreting the radical democratic paradigm. In: ROSENFELD, Michel, ARATO, Andrew (orgs.) Habermas on law and democracy: critical exchanges. Los Angeles: University California Press, 1998, p. 28.

82 HÄBERLE, Peter. Hermenêutica Constitucional: a sociedade aberta dos interpretes da Constituição: contribuição para a interpretação pluralista e "procedimental" da Constituição. Trad. Gilmar Ferreira Mendes. Porto Alegre: Sergio Antonio Fabris, 1997, p.23-24.
} 
Poder Constituinte Originário, deve-se ao intenso debate travado na Assembleia Nacional Constituinte que, por mais que a forma republicana fosse majoritariamente considerada adequada para a nossa comunidade política, a questão era a disputa acirrada em torno do sistema presidencialista e parlamentarista de governo.

É bem de ver que o parlamentarismo foi a forma de governo aprovada pela Comissão de Sistematização, reprovada, no entanto, no plenário. Realizado o plebiscito, a maioria optou pela forma republicana e pelo sistema presidencialista de governo. Assim, manteve-se a fórmula de governo republicana e presidencialista historicamente instituída no Brasil desde 1891, com os breves períodos de experiência parlamentarista de 1961 e 1963.

A segunda consulta popular foi realizada no referendo sobre a comercialização de armas de fogo e munições. $O$ art. 35 da Lei 10.826/2003 previa a proibição de comercialização de armas de fogo e munições em todo o território nacional. No entanto, o próprio $\$ 1^{\circ}$ do referido artigo condicionava a entrada em vigor da proibição à aprovação por meio de referendo popular. Realizado em 2005 pela convocação do Decreto Legislativo 780 do Senado Federal, a maioria popular optou pela possibilidade de comercialização da arma de fogo, o que impossibilitou a entrada em vigor do art. 35, retirando o dispositivo do Estatuto do Desarmamento.

Por mais que a Constituição de 1988 tenha pretendido aperfeiçoar a república com a utilização de mecanismos de participação popular, a pouca utilização da participação popular na construção do edifício constitucional nesses mais de 30 (trinta) anos de vigência do texto leva a um diagnóstico antidemocrático de que o establishment político desconfia de que a cidadania não poderá decidir questões de alta indagação jurídico-política, senão que, vez por outra, poderá apenas conferir legitimidade às decisões já tomadas pelo fechado círculo do poder.

A conquista de uma efetiva participação popular na consolidação do nosso projeto republicano não prescinde de uma reforma política, entendida como um processo contínuo e progressista de democratização das instituições públicas, de tal modo a se corrigir distorções do sistema e do regime. ${ }^{83}$

República se faz com alternância e temporalidade do poder. Nascida a partir da oposição à forma monárquica de poder, res publica significava para seus fundadores a negação à ideia do domínio de um só e a repulsa ao próprio nome que até então se tinha utilizado para nomear o Estado $^{84}$. Bem por isso, a primeira reforma no texto constitucional que modificou a estrutura

83 BONAVIDES, Paulo. Ciência Política,10a ed. São Paulo: Malheiros, 1996, p. 418.

84 JELLINEK, Georg. Teoría general del Estado. Mexico: Fundo de Cultura Economica, 2000. P, 617.Bem verdade, no entanto, que a palavra república pode assumir diferentes feições. Diríamos, assume o 
política foi a Emenda Constitucional n. 16/97 que, modificando o $\$ 5^{\circ}$ do art. 14, permitiu a reeleição por mais um mandato de 4 (quatro) anos de Presidente da República, Governadores de Estado e do Distrito Federal, dos Prefeitos e quem os houver sucedido ou substituído no curso do mandado. Pela primeira vez em nossa história republicana, permitiu-se ao Chefe do Executivo em âmbito nacional, estadual, distrital ou municipal a reeleição para um único período subsequente.

Veja-se que as modificações no sistema de estrutura política são feitas apenas para manter o status quo e jamais para alterar a estrutura substancial de poder.

A reforma política é tema que sempre se encontra em pauta no parlamento. Reconhecese, sem maiores dificuldades, a necessidade de se consolidar o projeto republicano e democrático a partir da reforma estrutural das instituições. Assim, por exemplo, a Câmara dos Deputados instituiu comissão para promover uma ampla reforma constitucional, possibilitando a participação popular através de audiência pública. Apresentou, pois, a Proposta de Emenda à Constituição 352/2013. Alguma das questões abordadas nessa reforma eleitoral são reações a decisões do Supremo Tribunal Federal ${ }^{85}$. A primeira delas é uma reação à decisão do STF no julgamento das ADI's 1351 e 1354 que julgaram inconstitucional reforma na Lei Orgânica dos

significado de acordo com o jogo de linguagem em que está inscrito, ou seja, de acordo com a gramática profunda de Wittgensteins (WITTGENSTEIN, Ludwig. Investigações filosóficas. 2. ed. Petropólis: Vozes, 1996). Aqui, no entanto, estamos nos referindo a uma forma de vida política que leva em conta a primazia do interesse comum, ou seja, "requer o engajamento da comunidade na condução da coisa pública e se faz expressar de maneira especial nos princípios, nas práticas e nos procedimentos que conformam as instituições" ( CUNHA, Alexandre, AQUINO, Luseni, MEDEIROS, Bernardo. A república como forma para pensar a democracia e o desenvolvimento no Brasil. In: BERCOVICI, Gilberto, CARDOSO JR., José Celso (orgs.). República, democracia e desenvolvimento: contribuições ao Estado brasileiro contemporâneo. Brasília: IPEA, 2013, p. 17).

85 Nos passos de Mark Tushnet, acontece o override legislativo quando há um controle de constitucionalidade em sentido fraco, onde se permite que o Poder Legislativo revise a decisão da Corte Constitucional (TUSHNET, Mark. Alternatives forms of judicial review. Michigan. Law. Review, n. 101, p. 2781-2802, p. 2787). Nesses casos, no entanto, não se pode falar que a tentativa de regulamentação do Congresso Nacional de um backlash próprio de um constitucionalismo democrático, onde a própria sociedade se insurge contra decisões oficiais: "Citizens engaged in backlash press government officials to enforce what those citizens believe to be the correct understanding of the Constitution. They press these demands so that officials will interpret the Constitution in ways that are democratically accountable" ( POST, Robert C., SIEGEL, Reva. Roe Rage: Democratic Constitutionalism and Backlash. Harvard Civil Rights-Civil Liberties Law Review, 2007; Yale Law School, Public Law Working Paper No. 131, p. 1-66. Disponível em http://ssrn.com/abstract=990968. Acesso em 25 out. 2015). Como conciliar a teoria do Constitucionalismo Democrático com a realidade brasileira de milhões de cidadãos em condições de subcidadania? Ou seja, como falar em exercício democrático se faltam a esses cidadãos condições mínimas para o exercício da democracia? Ora, há um habitus que cria e recria as condições de perpetuação da desigualdade com a participação cínica da intelectualidade brasileira ( SOUZA, Jessé. A construção social da subcidadania: para uma sociologia política da modernidade periférica. 2. ed. Belo Horizonte: UFMG, 2012). 
ISSN 1981-3694

(DOI): 10.5902/1981369433709

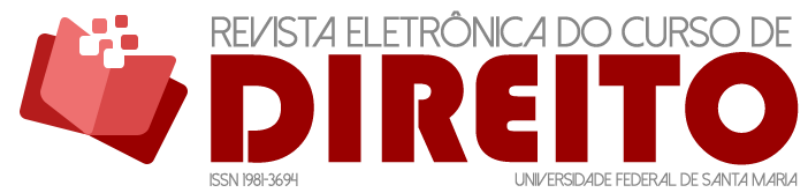

REPÚBLICA E CONSTITUIÇão DE 1988: OU CONSTITUIÇÃO SEM REPÚBLICA?

ALEXANDRE GUSTAVO MELO FRANCO MORAES BAHIA DIOGO BACHA E SILVA

Partidos Políticos que impunha a chamada cláusula de barreira, isto é, determinados critérios mínimos que os partidos políticos precisam atingir para alcançar uma vaga nas Casas Legislativas. Como reação necessária, o Congresso Nacional alçou tal questão para o nível constitucional. Assim, pois, o texto do art. $17, \S 3^{\circ}-\mathrm{A}$ da proposta original restabelece o requisito de $5 \%$ (cinco por cento) dos votos válidos para que o partido político obtenha direito a conquistar vaga no sistema proporcional.

Outro importante aspecto importante na reforma eleitoral proposta é o possível adiantamento com respeito ao financiamento de campanha eleitoral. Em 2011, o Conselho Federal da OAB ajuizou a ADI. n. 4650 questionando dispositivos legais da Lei 9.096/95 que permitiam a doação de pessoas jurídicas e físicas para campanhas eleitorais. O julgamento só veio a ser concluído em Setembro de 2015 quando a maioria julgou parcialmente procedente a ação para vedar contribuição das pessoas jurídicas para as eleições já em 2016, mantidas as disposições normativas sobre doações de pessoas físicas. $0 \$ 5^{\circ}$ do art. 17 da Proposta original, apresentada em 2013, delega ao partido político a opção entre o financiamento público ou financiamento privado ou, ainda, a combinação de ambos, estabelecendo regras no sentido de que as doações devem se destinar apenas aos partidos e coligações, excetuando-se as doações para os candidatos.

Alega-se que o sistema eleitoral proporcional vigente conduz a um sistema partidário de multipartidarismo exagerado, bem como a eventual eleição de candidato com pouca representatividade. Em termos clássicos, diz-se que o sistema majoritário favorece a um sistema bipartidário, enquanto que o sistema proporcional favorece um sistema multipartidário. 0 grande desafio das reformas eleitorais no Brasil é fazer com que se incremente o nível de representatividade e o fortalecimento dos partidos. De qualquer forma 0 sistema presidencialista de coalisão resultante do multipartidarismo é fonte inesgotável de corrupção, fisiologismo, estagnação no desenvolvimento democrático e instabilidade institucional, ingredientes estes que vimos dar seus frutos perniciosos recentemente com o impeachment da Presidente Dilma Rousseff.

A proposta de reforma política mencionada pretende estabelecer um modelo de sistema eleitoral conjugando critérios do sistema proporcional atual e critérios do sistema distrital. Assim, estabelece que o Tribunal Superior Eleitoral dividirá o território dos Estados e do Distrito Federal em circunscrições como forma de preencher os lugares da Câmara dos Deputados e da Assembleia Legislativa, enquanto que nas eleições municipais não haverá divisão. Os lugares 
serão preenchidos pela divisão dos votos pelo partido obtidos com a divisão total dos votos válidos pelo número de lugares para preencher. Cada candidato terá, então, que obter votos nominais correspondentes a, no mínimo, dez por cento do resultado da divisão do número de votos válidos na circunscrição pelo número de cadeiras a preencher. Por fim, os lugares não ocupados após a aplicação das regras proporcionais com distritais serão preenchidos pelos candidatos individualmente mais votados. Quais são os impactos dessa reforma para a estruturação da nossa república é questão que se mantém em aberto. Será mesmo que o sistema eleitoral permitirá um maior acesso aos indivíduos na estrutura de poder? Será que haverá o incremento da representatividade ao fortalecer as agremiações partidárias? Será que os detentores do mandato irão manter uma vinculação ideológica com os partidos pelos quais foram eleitos?

Importante passo para o fortalecimento dos partidos políticos já fora dado com o julgamento da fidelidade partidária pelo Supremo Tribunal Federal em que se consignou que, na interpretação do sistema proporcional constitucional vigente. 0 eleito se vincula a determinado partido político e tem seu programa e itinerário de atuação determinado pelo partido, razão pela qual seu descompromisso com o partido pelo qual fora eleito ocasiona a perda do mandato (STF, MS 26.6404/DF, rel. Min. Carmen Lúcia, j. 04.10.2007).

\section{CONCLUSÃO}

A República continua sendo um projeto inacabado no Brasil. No entanto, sabemos hoje que ideias-força como democracia, constitucionalismo e também República são sempre projetos, são sempre um “à venir”. ${ }^{86}$ Aliás, apenas continuaremos a ser uma democracia constitucional e um Estado Democrático de Direito se assim o for. A polis dos livres e iguais permanece como uma finalidade a se alcançar. É assim que podemos continuar lutando pela concretização do grande projeto da Constituição de 1988.

Perpassamos caminhos tortuosos: a abolição da escravatura; o fim do Império através de um golpe militar que visava construir uma sociedade de iguais, mas que pouco mais fez do que

\footnotetext{
${ }^{86}$ MOUFFE, Chantal. Pensando a Democracia Moderna com e contra Carl Schmitt. Cadernos da Escola de Legislativo. Belo Horizonte, n. 02, jul./dez. 1994. Disponível em: http://www.almg.gov.br/opencms/export/sites/default/consulte/publicacoes_assembleia/periodicas/ca dernos/arquivos/pdfs/02/teoria.pdf. Acesso em: 15 jun. 2020.
} 
transferir o poder de uma para outras elites. Os primeiros anos da república recheados de abusos de direitos e retrocessos democráticos, o sequestro da res publica por grupos civis e militares que se revezavam no poder, ora conferindo um verniz democrático, ora escancarando a nua face autoritária.

Finalmente, o novo fôlego da constituinte de 1987-1988, resultado não das forças que sempre estiveram à frente da república privatizada, mas dos anseios e lutas populares que sempre estiveram presentes em toda a história republicana, ainda que se insista por aqui em descrever o povo brasileiro como manso e pacífico. Ao longo de nossa história foi esse elemento, genuinamente republicano, o povo, que esteve presente e forçou mudanças. Muito se diz que as mudanças foram "pelo alto", contudo, elas só aconteceram porque foi preciso e isso porque houve e há pessoas mobilizadas que lutaram, que foram torturadas, que desapareceram, que foram mortas e que, com tudo, precipitaram as mudanças.

A Constituição de 1988 não alterou toda a realidade, de ausência de direitos efetivos, de sequestro da coisa pública, de domínio positivista da elite, de aparente esquecimento da política ${ }^{87}$, etc. Contudo, ela possui uma força sem precedentes, por ter sido construída sob grande luta, expectativa e participação popular. De lá para cá, se, de um lado, o sistema de presidencialismo de coalisão tem levado a seríssimos problemas institucionais e democráticorepublicanos $^{88}$, de outro os direitos e garantias fundamentais têm servido como chave para destrancar velhas estruturas e permitir o acesso a bens e direitos àqueles que deles nunca tiveram acesso. Não que ações pontuais do Judiciário possam substituir a política, como dissemos, mas, de alguma forma, vêm moldando um novo paradigma no qual aqueles que vivem sob a República se vêm como cidadãos, titulares de direitos dos quais, uma vez conseguidos, não permitem abrir mão, ao mesmo tempo em que projetam conseguir novos direitos em variadas frentes: redistribuição, reconhecimento e representação, para usarmos a trilogia das escalas da justiça de Nancy Fraser ${ }^{89}$.

A Nova República construída a partir de 1988, como projeto que é, nos tem colocado oportunidades únicas de construção de uma sociedade de livres e iguais. Apesar de aqui ter se focado principalmente em problemas, não se pode desconhecer as conquistas alcançadas.

\footnotetext{
${ }^{87}$ NOVAES, Adauto (org). O Esquecimento da Política. Rio de Janeiro: Agir, 2007.

${ }^{88}$ ABRANCHES, Sergio. Presidencialismo de coalização: o problema institucional brasileiro. Dados Revista de Ciências Sociais, Rio de Janeiro. v. 31, n. 1, 1988

${ }^{89}$ FRASER, Nancy. Escalas de Justicia. Barcelona: Herder, 2008.
} 


\section{REFERÊNCIAS}

ABRANCHES, Sergio. Presidencialismo de coalização: o problema institucional brasileiro. Dados Revista de Ciências Sociais, Rio de Janeiro. v. 31, n. 1, 1988.

ABRÃO, Paulo; TORELLY, Marcelo D. Justiça de Transição no Brasil: a dimensão da reparação. Revista Anistia Política e Justiça de Transição, Ministério da Justiça, n. 3, 2010.

ARANTES, Rogério Bastos. Judiciário \& Política no Brasil. SP: Idesp/Sumaré/Fapesp/Educ, 1997, p. 117 et seq. ARATO, Andrew. Procedural law and civil society: interpreting the radical democratic paradigm. In: ROSENFELD, Michel, ARATO, Andrew (orgs.) Habermas on law and democracy: critical exchanges. Los Angeles: University California Press, 1998.

BACHA E SILVA, Diogo. Ativismo no controle de constitucionalidade: a transcendência dos motivos determinantes e a (i)legítima apropriação do discurso de justificação pelo Supremo Tribunal Federal. Belo Horizonte: Arraes editores, 2013.

BAHIA, Alexandre; NUNES, Dierle. Crise da democracia representativa - infidelidade partidária e seu reconhecimento judicial. Revista Brasileira de Estudos Políticos; $n^{\circ}$ 100, jan/jun de 2010.

BALEEIRO, Aliomar. Constituições Brasileiras: 1891. Brasília: Senado Federal e Ministério da Ciência e Tecnologia, 2001.

BARACHO JÚNIOR, José Alfredo Oliveira. A interpretação dos Direitos Fundamentais na Suprema Corte dos EUA e no Supremo Tribunal Federal. In: SAMPAIO, José A. Leite (Org.). Jurisdição constitucional e os Direitos Fundamentais. Belo Horizonte: Del Rey, 2003.

BARBOSA, Ruy. Federação, Conservação. Jornal Diário de Notícias, 17.06.1889. In: BARBOSA, Ruy. Obras seletas. Rio de Janeiro: Fundação Biblioteca Nacional, v. 8.

BENTIVOGLIO, Julio. A história conceitual de Reinhart Koselleck. Dimensões, v. 24, 2010, p. 114-134.

BERMUDES, Sérgio. Introdução ao Processo Civil. $4^{\mathrm{a}}$ ed. Rio de Janeiro: Forense, 2006.

BONAVIDES, Paulo. Ciência Política,10. ed. São Paulo: Malheiros, 1996.

BONAVIDES, Paulo; AMARAL, Roberto. Textos políticos da história do Brasil, V. 2: império e $2^{\circ}$ reinado (1840-1889). 3 ed. Brasília: Secretaria Especial de Editoração e Publicações do Senado Federal, 2002.

BONAVIDES, Paulo; ANDRADE, Paes. Historia Constitucional do Brasil. 4. ed. Brasilia: OAB, 2002.

BONFÁ, Rogério L. Giampietro. “Com Lei ou Sem Lei”: as expulsões de estrangeiros na primeira república. Cadernos AEL, 2009, v. 14, n. 26, p. 183-214. 
BERCOVICI, Gilberto. A problemática da Constituição dirigente: algumas considerações sobre o caso brasileiro. Revista de Informação Legislativa. Brasília, n. 142, p. 35-51, abr./jun. 1999.

CARVALHO NETTO, Menelick de. A Constituição da Europa. In: SAMPAIO, José A. Leite (Coord.). Crise e desafios da Constituição. Belo Horizonte: Del Rey, 2004.

CARVALHO, José Murilo de. Os bestializados: o Rio de Janeiro e a República que não foi. São Paulo: Companhia das Letras, 1987.

CATTONI DE OLIVEIRA, Marcelo Andrade. Democracia sem espera e processo de constitucionalização: uma crítica aos discursos oficiais sobre a chamada transição política brasileira. In: CATTONI DE OLIVEIRA, Marcelo Andrade (org.). Constitucionalismo e História do Direito. Belo Horizonte: Pergamum, 2011.

CATTONI DE OLIVEIRA, Marcelo Andrade; SIQUEIRA, Gustavo Silveira. Pequeno Ensaio sobre a Injustiça: memórias secas de um tribunal de segurança nacional. [S.1: s.n] Sequência, n. 61, p. 111-125, dez. 2010.

CITTADINO, Gisele. Pluralismo, direito e justiça distributiva: elementos de filosofia constitucional contemporânea. 3. ed. Rio de Janeiro: Lumen Juris, 2004.

COSTA, Emília Viotti da. Da Monarquia à República: momentos decisivos. 9. ed. São Paulo: Unesp, 2010.

CRUZ, Álvaro Ricardo de Souza. Breve histórico do Supremo Tribunal Federal e do controle de constitucionalidade brasileiro. In: SAMPAIO, José A. Leite (org.). Crise e desafios da Constituição. Belo Horizonte: Del Rey, 2004.

CUNHA, Alexandre, AQUINO, Luseni, MEDEIROS, Bernardo. A república como forma para pensar a democracia e o desenvolvimento no Brasil. In: BERCOVICI, Gilberto, CARDOSO JR., José Celso (orgs.). República, democracia e desenvolvimento: contribuições ao Estado brasileiro contemporâneo. Brasília: IPEA, 2013.

DERRIDA, Jacques. Declarations of Independence. New Political Science Review. 1986.

DERRIDA, Jacques. Força de lei - o "fundamento místico da autoridade". São Paulo: Martins Fontes, 2007.

FAORO, Raymundo. A república inacabada. São Paulo: Globo, 2007.

FAORO, Raymundo. Os donos do poder: formação do patronato político brasileiro. 4. ed. São Paulo: Globo, 2008.

FAUSTO, Boris. Historia do Brasil. 2. ed. São Paulo: Universidade de São Paulo, 1995.

GARGARELLA, Roberto. La sala de máquinas de la Constitución: dois siglos de constitucionalismo en América Latina (1810 -2010). Buenos Aires: Katz editores, 2014. 
GOMES, Laurentino. 1889. Rio de Janeiro: Globo, 2013.

HÄBERLE, Peter. Hermenêutica Constitucional: a sociedade aberta dos interpretes da Constituição: contribuição para a interpretação pluralista e "procedimental" da Constituição. Trad. Gilmar Ferreira Mendes. Porto Alegre: Sergio Antonio Fabris, 1997.

HABERMAS, Jürgen. A constelação pós-nacional: ensaios políticos. São Paulo: Littera Mundi, 2001.

HABERMAS, Jürgen. Facticidad y Validez: sobre el derecho y el Estado democrático de derecho em términos de teoría del discurso. Trad. Manuel Jimenez Redondo. 6. ed. Madri: Trotta, 2010.

HABERMAS, Jürgen. Soberania popular como procedimento: um conceito normativo de espaço público. Novos Estudos Cebrap, n²6, março de 1990, p. 100-113.

HABERMAS. Jürgen. A inclusão do outro: estudos de teoria política. São Paulo: Loyola, 2002.

HAMBLOCH, Ernest. Sua majestade o presidente do Brasil - um estudo do Brasil constitucional (1889-1934). Brasília: Senado Federal, 2000.

HEIDEGGER, Martin. Cartas sobre o humanismo. 2. ed. Trad. Rubens Eduardo Frias. São Paulo: Centauro, 2005.

HEIDEGGER, Martin. Ser e tempo. 6. ed. Trad. Marcia de Sá Cavalcante Schuback. Petrópolis: Vozes, 2012.

HORTA, Raul Machado. Constituições Federais e pacto federativo. In: SAMPAIO, José Adércio Leite (coord.). Quinze anos de Constituição. Belo Horizonte: Del Rey, 2004.

HORTA, Raul Machado. Estudos de Direito Constitucional. Belo Horizonte: Del Rey, 1995.

JASMIN, Marcelo Gantus. História dos Conceitos e Teoria Política e Social: referências preliminares. Revista Brasileira de Ciências Sociais. v. 20, nº 57, fevereiro/2005, p. 27-38.

JELLINEK, Georg. Teoría general del Estado. Mexico: Fundo de Cultura Economica, 2000.

KIMMINICH, Otto. Jurisdição constitucional e o princípio da divisão de poderes. Revista de Direito Público, n. 92, p. 17-33, out./dez. 1989.

KOSELLECK, Reinhart. Futuro passado: contribuição à semântica dos tempos históricos. Trad. Wilma Patrícia Maas. Rio de Janeiro: Puc-Rio, 2006.

LIMA, Alcides de Mendonça. As novidades da constituição federal de 1967, segundo a emenda n. 1, de 1969. São Paulo: Juriscredi, 1971.

LOEWENSTEIN, Karl. Teoria de la Constitución. Barcelona: Ariel, 1978.

LOPES, José R. de Lima. O Direito na História. 3. ed. SP: Atlas, 2011. 
MENCK, José Theodoro Mascarenhas. A crise política de 1868 e a gênese do manifesto republicano de 1870. Cadernos ASLEGIS, n. 37, maio/agosto, 2009.

MEYER, Emílio Peluso Neder. Ditadura e responsabilização: elementos para uma justiça de transição no Brasil. Belo Horizonte: Arraes editores, 2012.

MOUFFE, Chantal. Pensando a Democracia Moderna com e contra Carl Schmitt. Cadernos da Escola de Legislativo. Belo Horizonte, n. 02, jul./dez. 1994. Disponível em:

http://www.almg.gov.br/opencms/export/sites/default/consulte/publicacoes_assembleia/peri odicas/cadernos/arquivos/pdfs/02/teoria.pdf. Acesso em: 15 jun. 2020.

NEQUETE, Lenine. O Poder Judiciário no Brasil a partir da independência: Império. V. II. Porto Alegre: Livraria Sulina, 1973.

OLIVEIRA, Lúcia Lippi. A questão nacional na Primeira República. São Paulo: Brasiliense; Brasília: CNPq, 1990.

PEREIRA, Anthony. Ditadura e repressão: o autoritarismo e o Estado de Direito no Brasil, no Chile e na Argentina. São Paulo: Paz e Terra, 2010.

POLETTI, Ronaldo. Constituições Brasileiras: 1934. Brasília: Senado Federal e Ministério da Ciência e Tecnologia, 2001.

POST, Robert C., SIEGEL, Reva. Roe Rage: Democratic Constitutionalism and Backlash. Harvard Civil Rights-Civil Liberties Law Review, 2007; Yale Law School, Public Law Working Paper No. 131, p. 1-66. Disponível em: http://ssrn.com/abstract=990968. Acesso em 25 out. 2015.

REIS, José. O tempo em Heidegger. Revista Filosófica de Coimbra, n. 28, 2005, p. 369-414.

RODRIGUES, Lêda Boechat. História do Supremo Tribunal Federal. Rio de Janeiro: Civilização Brasileira, 1965.

SALCEDO REPOLÊS, María Fernanda. Quem deve ser o Guardião da Constituição? Do poder moderador ao supremo tribunal federal. Belo Horizonte: Mandamentos, 2008.

SAMPAIO, José Adércio Leite. Teoria e prática do Poder Constituinte. Como legitimar ou desconstruir 1998- 15 anos depois. In: SAMPAIO, José Adercio Leite (org.) Quinze anos de Constituição. Belo Horizonte: Del rey, 2004.

SANTOS, Boaventura de Sousa. Para uma revolução democrática da justiça. 3. ed. São Paulo: Cortez, 2011.

SANTOS, Boaventura de Sousa. Pela mão de Alice: o social e o político na pós-modernidade. 3. ed. São Paulo: Cortez, 1997.

SOUZA JR., Antônio Umberto. O Supremo Tribunal Federal e as questões políticas. Porto Alegre: Síntese, 2004. 
SOUZA, Jessé. A construção social da subcidadania: para uma sociologia política da modernidade periférica. 2. ed. Belo Horizonte: UFMG, 2012.

STARLING, Heloisa Maria Murgel. Os senhores das gerais: os novos inconfidentes e o golpe de 1964. $4^{\mathrm{a}}$ ed. Petropólis: Vozes, 1986.

STEIN, Ernildo. Aproximações sobre hermenêutica. 2. ed. Porto Alegre: EdiPUCRS, 2010.

STRECK, Lenio Luiz. Jurisdição constitucional e decisão jurídica. 3. ed. São Paulo: Revista dos Tribunais, 2013.

TORRES, Ana Paula Repolês. Reforma e crise constitucional: um ensaio de teoria da Constituição. 2005. Dissertação (Mestrado em Direito Constitucional) - Programa de PósGraduação em Direito da Faculdade de Direito da UFMG, Belo Horizonte, 2005.

TUSHNET, Mark. Alternatives forms of judicial review. Michigan. Law. Review, n. 101, p. 27812802.

VATTIMO, Gianni. Introdução a Heidegger. Lisboa: Instituto Piaget, 2000.

VIANA, Oliveira. O ocaso do Império. Brasília: Edições do Senado Federal, 2004.

VIANNA, Túlio. Julgando de barriga cheia. Jornal Estadão. São Paulo. 11 nov. 2012. Disponível em: http://alias.estadao.com.br/noticias/geral,julgando-de-barriga-cheia-imp-,958750. Acesso em: 14 jun. 2020.

VIEIRA, Oscar Vilhena. Supremo Tribunal Federal: jurisprudência política. 2. ed. São Paulo: Malheiros, 2002.

WITTGENSTEIN, Ludwig. Investigações filosóficas. 2. ed. Petropólis: Vozes, 1996.

ZANELLA, Camila. Análise Histórico Educacional do Positivismo Durante a Primeira República. XXVII Simpósio Nacional de História: conhecimento histórico e diálogo social. Natal, 22-26 de julho de 2013, p. $2 . \quad 20$ Disponível http://www.snh2013.anpuh.org/resources/anais/27/1371246624_ARQUIVO_artigoanpuh2013.pdf .2013, p. 2.). Acesso em: 15 jun. 2020. 


\section{COMO FAZER REFERÊNCIA AO ARTIGO (ABNT):}

BAHIA, Alexandre Gustavo Melo Franco. BACHA e SILVA, Diogo. REPÚBLICA E CONSTITUIÇÃO DE 1988: OU CONSTITUIÇÃO SEM REPÚBLICA?. Revista Eletrônica do Curso de Direito da UFSM, Santa Maria, RS, v. 15, n. 02, e33709, maio/ago. 2020. ISSN 1981-3694. DOI: http://dx.doi.org/10.5902/1981369433709. Disponível em: https://periodicos.ufsm.br/revistadireito/article/view/33709 Acesso em: dia mês. ano.

Direitos autorais 2020 Revista Eletrônica do Curso de Direito da UFSM

Editores responsáveis: Rafael Santos de Oliveira e Angela Araujo da Silveira Espindola

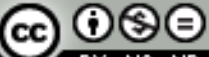

Esta obra está licenciada com uma Licença Creative Commons Atribuição-NãoComercial-SemDerivações 4.0 Internacional.

\section{SOBRE OS AUTORES}

AleXandre Gustavo Melo franco de Moraes BaHIA

Bolsista em Produtividade do CNPq (PQ2 - 2016-2019, 2020-2023). Possui graduação em Direito pela Universidade Federal de Minas Gerais (2001), Mestrado em Direito Constitucional pela Universidade Federal de Minas Gerais (2004) e Doutorado em Direito Constitucional pela Universidade Federal de Minas Gerais (2007). Pós-Doutor pelo Instituto de Saúde Pública da Universidade do Porto. Atualmente é Professor Adjunto do Departamento de Direito da Universidade Federal de Ouro Preto e do IBMEC-BH. Atua principalmente nos seguintes temas: Direitos Fundamentais, Estado Democrático de Direito, Minorias, Ativismo e Reforma do Judiciário. Membro da Comissão Nacional da Diversidade Sexual (OAB) e Presidente da Comissão Estadual da Diversidade Sexual (OAB-MG). Membro do IBDP (Instituto Brasileiro de Direito Processual).

\section{DIOGO BACHA E SILVA}

Doutorado em Teorias Jurídicas Contemporâneas pela Universidade Federal do Rio de Janeiro - UFRJ (2019), mestrado em Constitucionalismo e Democracia pela Faculdade de Direito do Sul de Minas - FDSM (2012) e graduado em direito (2008). Atualmente é professor da Faculdade de São Lourenço, associado do Conselho Nacional de Pesquisa e Pós-Graduação em Direito e associado do Instituto de Hermenêutica Jurídica. Membro da rede para o constitucionalismo democrático latinoamericano. Tem experiência na área de Direito, com ênfase em Direito Constitucional, atuando principalmente nos seguintes temas: estado democrático de direito, constituição, jurisdição constitucional, impeachment e direitos fundamentais. Pesquisa em Decolonialidade, Constitucionalismo latino-americano e jurisdição constitucional decolonial com ênfase na desconstrução derridiana. 